\title{
Kuzeybatı İran'daki Urartu Yazıtlarındaki Savaş ve Propaganda İfadeleri
}

\author{
Nezahat CEYLAN ${ }^{1}$ ve Murat ÇİFTÇİ ${ }^{2}$
}

\section{$\ddot{\mathrm{O} z}$}

MÖ XIII. ve IX. yüzyıllar arası Uruatri-Nairi beylikler dönemi olmak üzere Doğu Anadolu Bölgesinde kurulup MÖ IX. ve VI. yüzyıllar arasında hüküm süren Urartu Devleti genişleme politikaları doğrultusunda ülkesinin dört bir yanına askeri seferler düzenlemiştir. Bu seferlerin önemli bir bölümü Kuzeybatı İran toprakları üzerine yapılmıştır. Burası yaşam için elverişli iklimi, akarsuları, yer altı ve yer üstü zenginliklerinin yanında stratejik öneme sahip olan yol güzergahları nedeniyle Urartu krallarının ilgi odağında bulunan bir coğrafyadır. Özellikle Urartu'nun güney komşusu olan Asur Devletinin de yoğun ilgilendiği bu bölge bu iki büyük güç arasında birçok mücadelelere sahne olmuştur. Urartu kralları bu bölge üzerinde kalıcı olmak adına çeşitli faaliyetler yürütmüşlerdir. Bu faaliyetlerin bir yönünü yazıtlar aracılığıyla yapılan propaganda faaliyetleri oluşturmaktadır. Urartu krallarının Kuzeybatı İran coğrafyasının farklı yerlerine bıraktıkları yazıtlar içerik bakımından birçok propaganda ifadesi içermektedir. Bir nevi bölge hakimiyetinin tapusu niteliğinde olan bu yazıtlarda tanrısal gücün çatısı altında kralın erdemleri, faaliyetleri ve haklı kral olduğu vurgusu yapılarak bölge hakimiyeti tescillenmek istenmiştir.

Anabtar Kelimeler: Urartu, Kuzeybatı İran, Yazıt, Propaganda

War and Propaganda Statements in Urartian Inscriptions in Northwest Iran

\begin{abstract}
The Urartu State, which was established in the Eastern Anatolia Region and ruled between the IX and VI centuries $\mathrm{BC}$, organized military expeditions to all over the country in line with its expansion policies. A significant portion of these expeditions were carried out over the northwestern Iranian lands. This is a geography that is at the center of attention of the Urartu kings due to its suitable climate, rivers, underground and aboveground riches as well as road routes, which are of great strategic importance. Assyrian state, the southern neighbor of Urartu, also showed great interest and this region has witnessed many clashes between these two great powers. Urartu kings carried out various activities in order to be permanent in this region. One aspect of these activities is propaganda activities carried out through inscriptions. The inscriptions left by the Urartian kings to different parts of the northwestern Iranian geography contain many propaganda statements in terms of content. It was emphasized that in these inscriptions, which are a kind of act of regional sovereignty under the roof of divine authority, virtues, activity and the rightful king were underlined, and the sovereignty of the region wanted to be registered.
\end{abstract}

Key Words: Urartian, Northwest Iran, Inscription, Propaganda

\section{Atıf İçin / Please Cite As:}

Ceylan, N. ve Çiftçi, M. (2021). Kuzeybatı İran'daki Urartu yazıtlarındaki savaş ve propaganda ifadeleri. Manas Sosyal Arasttrmalar Dergisi, 10(2), 1369-1388.

Geliş Tarihi / Received Date: 13.03.2021

Kabul Tarihi / Accepted Date: 02.04.2021

\footnotetext{
${ }^{1}$ Doç. Dr. - Kırgızistan-Türkiye Manas Üniversitesi Edebiyat Fakültesi, Tarih Bölümü, n.ceylan@atauni.edu.tr

(iD ORCID: 0000-0002-9889-7279

${ }^{2}$ Doktora Öğrencisi - Atatürk Üniversitesi Türkiyat Araştırmaları Enstitüsü Tarih Bölümü, murat.ciftci.4004@gmail.com

(iD ORCID: 0000-0002-1297-1213
} 


\section{Kuzeybatı İran Fiziki ve Tarihi Coğrafyası}

İran, Ekvatorun kuzeyinde $25^{\circ}-40^{\circ}$ kuzey enlemleri arasında yer almaktadır. İran Türkiye'nin komşuları arasında yüzölçümü en büyük olan ülkedir. İran'n kuzeybatısında Azerbaycan (432 km) ve Ermenistan $(35 \mathrm{~km})$, kuzeyinde Hazar Denizi; kuzeydoğusunda Türkmenistan $(992 \mathrm{~km})$, doğusunda Pakistan $(909 \mathrm{~km})$ ve Afganistan $(936 \mathrm{~km})$, batısında Türkiye $(499 \mathrm{~km})$ ve Irak $(1.458 \mathrm{~km})$, güneyinde Basra Körfezi ve Umman Körfezi yer almaktadır. İran, doğuda Pencap Nehri, batıda Dicle ve Fırat, kuzeyde Hazar Denizi, güneyde Basra Körfezi ve Umman Denizi arasında, yüksek bir bölgedir. İran Platosu; doğuda Tibet, batıda Anadolu Platosu ile komşudur (Atalay,2011, s.30 vd.; Ceylan, 2015c, s. 8 vd.; Ceylan ve Ceylan, 2016, s. 12-13; Şimşek, 2020, s. 20-22).

İran'ın Kuzeybatısındaki Azerbaycan Platosu, İran Platosunun büyük kısmını oluşturmaktadır. Bu plato Mezopotamya, Kafkaslar Bölgesi ve Hazar Denizinin arasında üçgen şeklindedir (Perfereç, 2007, s. 8 vdd.). Kuzeybatı bölümünün yüksek karlı sıradağları bu bölgenin sınır duvarını oluşturmaktadır. Doğuda Kaflankuh, güneyde Sehend Dağı, kuzeydoğuda Savalan ve Bozkuş Dağları, batıda Urmiye Gölü bu alanı çevrelemektedir. İran Azerbaycanının jeolojik ve morfolojik yapısı buraya özel bir görünüm kazandırmaktadır. Bu görünümü yüksek dağlar, engebeli yüzey şekilleri ve yükseltilerin arasındaki düzlük ve çukur yerler oluşturmaktadır. Genel olarak İran Azerbaycan'ına dağlık bir bölge diyebiliriz (Ceylan, 2015c, s. 1; Ceylan ve Jalali, 2018, s. 674; Hamaçi, 1991, s. 396).

Kuzeybatı İran Bölgesi’nin iklim, bitki örtüsü ve akarsularına bakıldığında; yılın en sıcak ayları Temmuz ve Ağustos aylarıdır. Azerbaycan'ın dağlık yerlerinde genellikle yaz mevsimi serin geçer. Kışın hava oldukça soğuk olup, kar Nisan Ayı'nın sonuna kadar erimemektedir (Efşar, 1990, s.13). Batı Azerbaycan'ın kendine has bir bitki örtüsü vardır. Dağ etekleri ve yamaçlarında kar ve yağmur yağışı fazla olduğundan kuraklık daha azdır. Bu şartlar bitki örtüsü için uygun ortamı hazırladığından bölgede bitki örtüsü çeşitliliği fazladır. Batı Azerbaycan'ın \% 49.3’ü meralarla kaplıdır. Dağ stepleri ve düzlük yerlerin aras1 3.3 milyon hektar meralık alana sahiptir. Batı Azerbaycan'da düzlüklerdeki su kenarlarında step bitki örtüsü bulunmaktadır. Dağ stebi olarak bilinen bitki örtüsü özellikle Karadağ, Erdebil’in doğusu ve Halhalın doğusundaki dağlarda yer almaktadır. Doğu Azerbaycan'ın en önemli kışlık merası, Mogan Ovası'dır. Kışın hayvanlarını beslemek isteyen yaylacılar bu meralardan faydalanırlar. Bu meralara düşen yıllık ortalama yağış miktarı 300-600 mm.'dir. Bölgede diğer önemli mera şekli yaylalardır. Yaylacılar mayısın başından Eylülün başına kadar bu yaylalardan faydalanırlar. Yılda iki kez ilkbaharın sonunda ve sonbaharın başında bu meralar kullanılır (Hamaçi, 1991, s. 59 vd.). Kuzeybat1 İran Bölgesi’nin Doğu Azerbaycan Bölümü'nde Aras Nehri (Ceylan, 2008, s. 39-40; Tuncel, 1991, s. 332 vd.), Kız1l Uzun Nehir (Efşar, 1990, s.25 vd.), Acı Çay (Perfereç, 2001, s. 12) gibi akarsular yer alırken Batı Azerbaycan Bölümü’nde Küçük Zap, Sarısu Nehri, Ovacık Nehri, Zengimar Nehri, Dir Alisu, Zerin Dere ve Zorlay Çay gibi başlıca akarsular bulunmaktadır (Efşar, 1990, s. 61; Perfereç, 2001, s. 19 vd.).

Kuzeybatı İran'daki toprağın verimliliği, iklim koşullarının ve bitki örtüsünün uygun olması, avcılık ve toplayıcıllk açısından yeterli şartların bulunması, bölgenin tarihin çeşitli dönemlerinde yerleşim görmesine zemin hazırlamıştır. Kuzeybatı İran'da yerleşmelerin bulunduğu yerlerde tarım yapmak mümkündü. Bölgede, yağmur ve kar yağışı yeterli miktardaydı. Yerleşmelerin yakınında, günlük ihtiyacı karşılayacak su kaynakları yer almaktaydı. Avcılık ve toplayıcilığı sürdürmek için hayvan türleri bulunmaktaydı (Hole, 1987, s. $177-179$.).

Urmiye Gölü uygun yaşam koşullarına sahip olduğu için Erken Paleolitik Dönem'de yerleşime sahne olmuştur. Tebriz'in güneydoğusunda yer alan Kurugöl kıyılarında anataş, balyoz ve dövücü taşlar ele geçirilmiştir. Ayrıca Mahabat'ın ve Shend'in çevresindeki ırmak kenarlarında da anataş, dövücü taş, yontucu taş ve balyoz tespit edilmiştir. Bu keşifler yapılmadan önce Paleolitik Dönem ile ilgili bilinen yerleşim yeri Urmiye Gölü’nün batısına konumlandırılan Temteme Mağarasıdır (Ceylan, 2015c, s. 24-25; Ceylan ve Ceylan, 2016, s. 13; Perfereç, 2007, s. 35 vd.).

Kuzeybatı İran Neolitik ve Kalkolitik Dönem yerleşimlerine de sahne olmuştur. Neolitik yerleşmelerden en önemlisi MÖ 7900-7500 yılları arasına tarihlendirilen Hacı Firuz'dur. Ayrıca Salmas Ovası'nda yer alan Ahranjan Tepe, IX. Hasanlu olarak bilinen ve MÖ 5000-4500 yilları arasına tarihlendirilen Dalma Tepe ve Urmiye'nin güneybatısında bulunan Pizdili Tepe Neolitik Döneme ait çanak, çömlek, değirmen taşı, dibek vb. buluntu veren merkezlerdir (Dyson ve Young, 1960, s. 19 vd.; Hacızade, 1995, s. 25; Nissen, 2004, s. 26 vd.; Talai, 1983, s. 51 vd.). Bölgede Kalkolitik yerleşime sahne olmuş yerler; cilalı, astarlı ve kahverengi nakışı keramikleriyle Yanık Tepe (Perfereç, 2001, s. 40 vd.; 
Reisnia, 1989, s. 1vd) ve gri, bej ve parlak kırmızı astarlı olup geometrik nakışlarla süslü keramikleri olan Göy Tepe'dir (Brown, 1948, s. 21; Hacızade, 1995, s. 28vd.).

Kuzeybatı İran'ın Orta Tunç Çağına bakıldığında Urmiye Gölü'nün güneybatısı ve güneyinde yayılan koyu kahve ve kırmızı renkli nakışlı keramikleriyle Habur Kültürü (Dyson, 1965, s. 193), Kuzeybatı, batı ve İran'ın merkezi platosunda Kızılvank Kültürü, Urmiye ve Van Kültürü olarak da adlandırilan, bej ve kırmızı renk ağırlıklı kap kacak ve nakışlı çanak çömlekleriyle Urmiye Bölgesi Çanak Çömlek Kültürü görülür (Burney ve Lang, 1972, s. 42 vd.; 1975, s. 149 vd; Edward, 1981, s. 115).

Urartu tarihi coğrafyası incelendiğinde en önemli yayılım alanlarından birinin güney ve güneydoğu yönünde olduğu görülür. Özellikle Kuzeybatı İran coğrafyası Urartu krallarının ilgi gösterdiği bir yerdir. Bu coğrafya içerisinde yer alan Urmiye Bölgesi rakım olarak Van Gölü'nden 400-450 metre daha düşük bir seviyede olup 1274 metre yükseltiye sahiptir. Bu sebeple iklim yönünden Van Gölü Havzası ve Doğu Anadolu'nun diğer bölgelerine nazaran daha 1lımandır. Asur metinlerinde Nairi'nin Aşağı Denizi olarak bahsedilen Urmiye Gölü bölgenin önemli su kaynaklarından birini oluşturmaktadır. Tarihin erken dönemlerinden itibaren yerleşim gören Urmiye Gölü çevresi askeri ve kültürel yönden kıymetinin yanında komşu ülkelere sağladığı ulaşım kolaylığıyla da stratejik öneme sahip bir bölgedir (Ceylan ve Ceylan, 2016, s. 12; Çilingiroğlu, 1997, s. 6; Salvini, 2006, s. 24-25).

Urartu'nun güney ve güneydoğu yönlü olmak üzere tarihi coğrafyasının aydınlatılmasındaki temel kaynaklar Urartu ve Asur krallarına ait olan yazıtlardır. Urartu krallarından Menua'ya ait olan Karagündüz ve Taştepe; Sarduri II'ye ait olan Hazinekap1 ve Sığındıl; Rusa I'e ait olan Mahmud Abad ve Mergeh Karvan ve Argişti II'ye ait olan Razlık ve Kırkızlar yazıtları ile Asur krallarına ait yıllıklar bu konuda büyük bir önem arz etmektedir (Ceylan ve Ceylan, 2016, s. 15 vd.).

Kuzeybatı İan bölgesinde yer alıp Urartu ve Asur askeri seferlerinin odak noktasında olan önemli ülkelerden biri Manna Ülkesidir. Doğal kaynakları ve konumu bakımından hem Asur hem de Urartu için stratejik bir konumda olan bu ülkenin lokalizasyonu hakkında bilim insanlarının farklı görüşleri vardır. Fakat genel olarak Urmiye Gölü'nün güney kıyılarına yerleştirilmektedir. (Çilingiroğlu, 1994, s. 56-57; Thureau-Dangin, 1912, s. 7-8).

Urartu ve Asur kaynaklarında adı geçen ve Urmiye Gölü'nün güneyinde yer aldığı düşünülen ülkelerden birisi de Barşua Ülkesidir. Asur yazılı kaynaklarından yola çıkılarak Parşua olduğu belirtilen bu yerin Urmiye Gölü’nün güneyi veya Orta Zagros Dağları olduğu ileri sürülmektedir. (Çilingiroğlu, 1994, s. 50; Diakonof ve Kashkai, 1981, s. 62-63). Urartu yazıtlarında adı geçen ve Urartu için çok önemli olan yerlerden diğeri ise Mešta kentidir. Günümüzde Kuzey Batı İran'da yer alan ve Hasanlu olarak adlandırılan bu yer Asur yazılı kaynaklarında Gilzanu Ülkesi olarak geçmektedir (Ceylan, 2015a, s. 189). Buştu Ülkesi de yazıtlarda bahsedilen ülkelerden birisidir. Urmiye Gölü’nün güneyine konumlandırılan bu ülke Manna ve Parsua Ülkeleri arasına yerleştirilmektedir (Diakonof ve Kashkai, 1981, s. 23; Van Loon, 1975, s. 204).

Urartu'nun güneydoğu yayılımı doğrultusunda Urartu çivi yazılı belgelerinde önemli konumda olan Hubuşkia Bölgesi, Ulhu Ülkesi, Bastam ve Musaşir kentlerinin isimleri geçmektedir. Yeri kesin olmamakla birlikte Hubuşkia Bölgesi, Zagros dağlarına konumlandırılmaktadır. Fakat Zagros Dağlarının batısında mı yoksa doğusunda bulunan Yüksekova'da mı yer aldığı belli değildir (Salvini, 2006, s. 104). Ulhu Ülkesinin de konumu kesin olarak tespit edilememiştir. Fakat genel kanı olarak Urmiye Gölü’nün kuzeydoğusunda yer alan Marand Ovasına konumlandırilmaktadır (Muscarella, 1986, s. 465-475). Bastam kenti Kuzeybat1 İran'da Akçay Nehri'nin sol kıyısında bulunmaktadır (Ceylan, 2015b, s. 137; Kleiss, 1980, s. 299-304). Çok önemli bir dini merkez olup Urartu-Asur mücadelelerine sahne olan Musaşir kentinin yeri de henüz tam olarak tespit edilememiştir. Fakat Türkiye-İran-Irak sınırlarının birleştiği noktanın güneyinde yer alan Revanduz bölgesinde bulunduğu düşünülmektedir (Ceylan, 2015b, s. 137 vd.; Diakonof ve Kashkai, 1981, s. 58; Kleiss ve Hauptman, 1976, s. 28).

\section{Kuzeybatı İran'da Urartu Egemenliği}

Kuzeybatı İran'ın Eskiçağına bakıldığında tarihsel süreç içerisinde birbirinden farklı siyasi güçlerin bu coğrafyada hüküm sürdüğ̈̈ görülür. Bu siyasi güçlerden biri de Urartu Devletidir. Doğu Anadolu'da bulunan yerel krallıkların bir araya gelmesiyle oluşan Urartu Devleti, hakimiyet dönemi olan MÖ IX. ve VI. Yüzyıllar arasında genişleme siyaseti doğrultusunda İran'nn kuzeybatı bölgesinde de faaliyet göstermiştir (Ceylan, 2015a, s. 189 vdd.; Ceylan, 2015b, s. 137 vdd.; Ceylan ve Ceylan, 2016, s. 11; Ceylan ve Günaşd1, 2017, s. 319). 
Urartu'nun ilk kralı olan Arame'den sonra Urartu tahtına Sarduri I (MÖ 832-825) geçmiştir. Sarduri I Dönemi'nde Van Gölü ve çevresi tamamen Urartu hakimiyetine girmiştir. Ayrıca Kuzeybatı İran'ın bir bölümünde de hakimiyet sağlanmıştır. Sarduri I’in çağdaşı konumunda olup Kuzeybatı İran topraklarında fetih hareketlerinde bulunan Asur Devleti kralı Salmanasar III (MÖ 858-824) Urartu'nun bölgedeki faaliyetlerine engel olamamış ve bunun sonuncunda Urartu Devleti sınırları Musaşir Ülkesine kadar dayanmıştır (Frankel, 1979, s. 10 vd.; Piotrovsky, 1959, s. 80 vd.).

Sarduri I'den sonra Urartu tahtına İşpuini (MÖ 825-810) geçmiştir. İşpuni ve oğlu Menua'nın ortak krallık dönemine ait olan Kelişin ve Karagündüz yazıtları Kuzeybatı İran fetih hareketleri hakkında önemli bilgiler verir. Kelişin yazıtında Ön Asya dünyasının en önemli dini merkezlerinden biri olan Musaşir/Ardini kentinin (Hchl, 1953-57, no.9; Payne, 2006, s. 55 vd.; Sayce, 1882, s. 663-664 no.56; UKN, 1960a, no.19), Karagündüz yazıtında ise Meşta, Qua, Şaritu, Nigibi ve Barşua kentlerinin Urartu egemenliğine geçişinden bahsedilir (CICh, 1928-35, no.15, tab. 43-44; Hulin, 1958, s. 237, no:3; Salvini, 1984, s. 57-62). Yine bu baba oğulun ortak krallık dönemine ait bir başka yazıt olan Kalatgah yazıtında ise Sapaili Ülkesinin ele geçirilerek Urartu'nun bu bölgedeki hakimiyetinin güçlendirildiği vurgulanır (Ceylan, 2015c, s. 257; Ceylan ve Ceylan, 2016, s. 16; Payne, 2006, s. 35).

Kuzeybatı İran Bölgesi madenleri, ormanları, otlakları ve hayvanları bakımından zengin olduğu için Urartu'ya çok cazip gelen bir bölgedir (Kroll, 2011, s. 150 vd.). Menua zamaninda da buraya seferler devam etmiştir. Menua'ya ait olup Urmiye Gölü’nün batı kıyısında bulunan Taştepe yazıtında belirtilenlere göre Meşta/Hasanlu kenti ve Manna Ülkesi Urartu hakimiyetine girmiştir. Böylelikle İşpuini Dönemi’nde başlatılan Kuzeybatı İran seferlerinin oğlu Menua Dönemi'nde de devam ettiği ve elde edilen başarılar sayesinde Asur'un faydalandığı bölge zenginliğinin artık Urartu'nun eline geçtĭgi anlaşılmaktadır (CTU, 2008a, no.A5-9; UKN, 1960a, no. 29; Zimansky, 1985, s. 40).

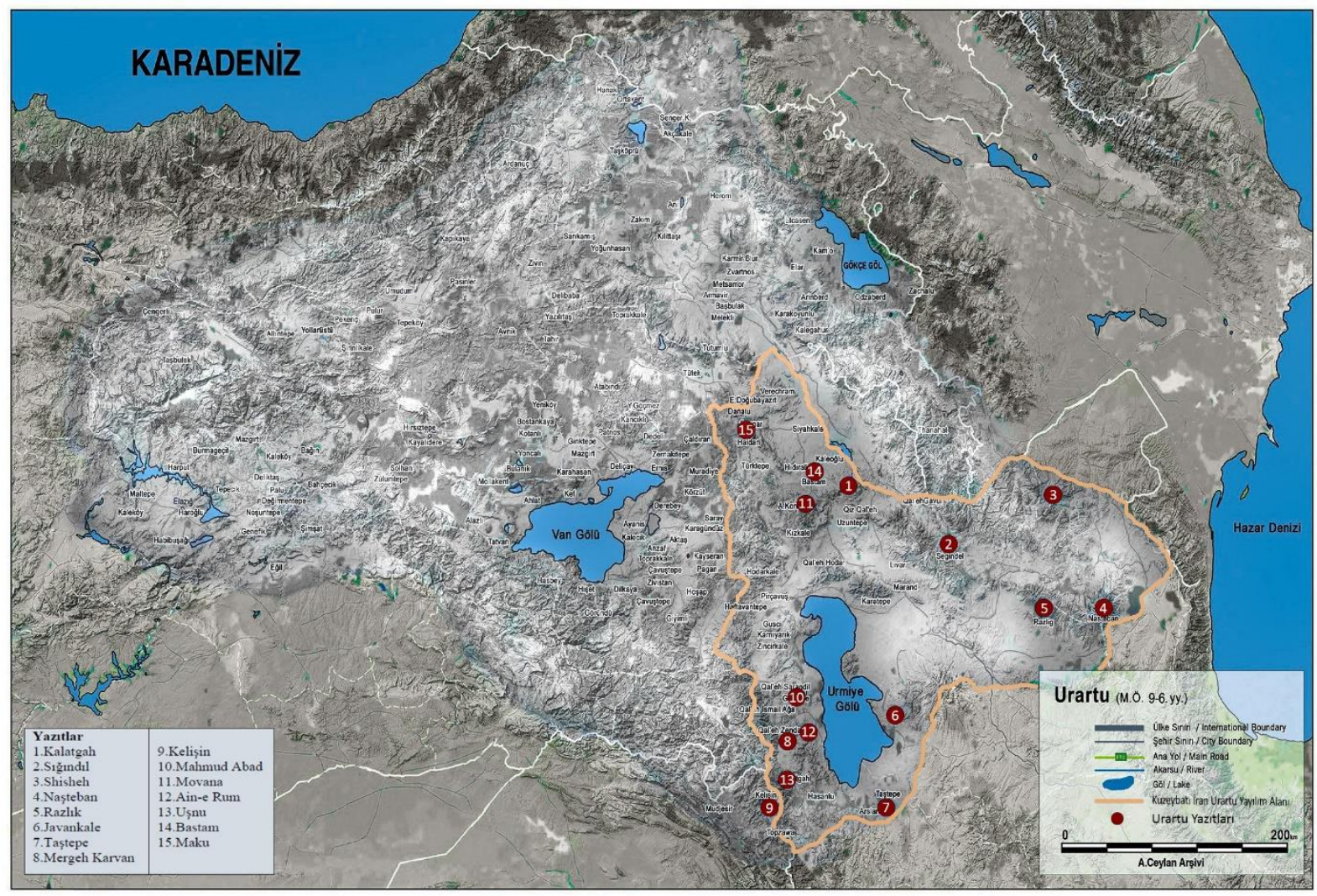

Harita 1. Urartu Yaynlimı ve Kuzeybatı Iran Hakimiyet Sabast

Menua'dan sonra Urartu tahtına Argişti I (MÖ 786-764) geçmiştir. Kralın dönemine ait olan Horhor yıllıklarında belirtilenlere göre Urartu Ülkesini genişletme politikaları doğrultusunda dört bir yanda fetih hareketlerinde bulunmuştur. Bu fetih hareketlerinin önemli bir yönü ise Kuzeybatı İran topraklarıdır. Büyük rakibi Asur'un bölge halkını Urartu'ya karşı kışkırtma teşebbüsleri ve buranın stratejik konumu bu topraklara sefer yapılmasını kaçınılmaz hale getirmiştir. Argişti I Dönemi’ne ait olan Javankale yazıtında 
Asur ordusunun mağlup edildiği, Manna Ülkesinin tekrar ele geçirildiği ve bölgede çeşitli nüfus politikaları uygulandığı belirtilmektedir (Ceylan, 2015c, s. 271 vd.; Payne, 2006, s. 150 vd.; Salvini, 2005, s.241 vd.).

Argişti I'den sonra Urartu tahtına geçen Sarduri II (MÖ 764-734) Dönemi’nde de bölgede uygulanan fetih politikaları devam etmiştir. Sarduri II Dönemi'ne ait olan Sığındıl yazıtına göre Puluadi ve Ba[ ]şadi ülkeleri fethedilmiş ve burada kalıcılık sağlamak adına imar faaliyetlerinde bulunulmuştur (Ceylan, 2015c, s. 259; Meklikişvili, 1960b, 29 vd.; UKN, 1960a, no. 13). Sarduri II'den sonra yerine geçen Rusa I (MÖ 734714) tarihin erken dönemlerinden itibaren yerleşime sahne olan Urmiye Gölü çevresi ile yakından ilgilenmiştir. Çünkü bu bölge askeri ve kültürel açıdan kıymetinin yanında komşu bölgelere sağlanan ulaşım kolaylıkları yönüyle de stratejik bir önem arz etmektedir (Ceylan ve Ceylan, 2016, s. 12; Reisnia, 1989, s. 22 vd.). Rusa I bölgenin bu cazip özelliklerinden dolayı buraya birçok sefer düzenlemiştir. Bu serler hakkındaki bilgileri Mahmud Abad (Payne, 2006, s. 271; Salvini, 1977, s. 125-136), Mergeh Karvan (Kleiss, 1977, s. 81-82; Salvini, 1984, s. 79 vd.) ve Movana (A. Salvini ve M. salvini, 2002, s. 5 vd.; Mayer, 2013, s. 84 vd.) yazıtlarından öğrenmekteyiz. Bu yazıtlarda Musaşir kralı Urzana’nın Urartu karşıtı düşmanca tavırları, Musaşir'in ele geçirilişi ve tanrılara sunulan adaklardan bahsedilmektedir (Ceylan ve Ceylan, 2016, s. 19).

Rusa I'in Kuzeybatı İran bölgesindeki faaliyetleri ezeli düşmanı olan Asur tarafindan iyi karşılanmamıştır. Bölge üzerinde Urartu-Asur mücadelesinin devam ettiği bu dönemde Asur tahtına Sargon II (MÖ. 721-705) geçmiştir. Asur yanlısı Manna Ülkesi kralının Urartu'nun destek verdiği beylikler tarafindan öldürülmesi, Sargon II'nin Urartu'ya karşı kesin bir sonuç elde etmek için sefer hazırllğına girişmesine neden olmuştur. Sargon II'nin oğlu Sanherib tarafindan yönetilen Asur istihbarat teşkilatının Asur kralına verdiği bilgilere göre Urartu Devleti Kimmer saldırısına uğramıştır. Urartu'nun Kimmer akınları karşısındaki başarısız tutumunu firsat bilen Sargon II MÖ 714 yılında Urartu’ya karşı meşhur 8. Seferine çımıştır. Urmiye Gölü civarında hakimiyet kurarak Musaşir kentini ele geçiren Sargon II karşısında tutunamayan Rusa I savaşı kaybetmiştir. Bu başarısızlığı kendine yediremeyen Urartu kralı intihar etmiştir (ARAB I, 1926, s.5-6, 140 vdd.; Erzen, 1992, s. 35-37; Tarhan, 1972, s. 96).

Urartu'nun bu çalkantılı döneminde Argişti II (MÖ 714-685) tahta çıkmıştır. Argişti II devletin kötü gidişatının önüne geçmek adına imar faaliyetlerine hız vermiş ve fetih hareketlerine devam etmiştir. $\mathrm{Bu}$ kapsamda Kuzeybatı İran topraklarına seferler düzenlemiştir (Salvini, 2006, s. 110 vd.). Bu krala ait olup İran coğrafyasında bulunan Razlık (Benedict, 1965, s. 35-40, no. 2; CTU, 2008a, no. A11-4) ve Kırkızlar (Benedict, 1965, 35-40, no. 1; UKN II, 1971, no.446) yazıtlar1 buraya yapılan seferler hakkında bilgi vermektedir. İçerik bakımından benzer konumda olan bu yazıtlarda Urartu güçlerinin Hazar Denizi yakınlarına kadar ilerleyip Arhu, Usulu, Buqu, Girduni, Gituhani ve Tuisdu gibi ülkeleri ele geçirdiği belirtilir. Argişti II'nin İran topraklarında bu denli başarılı faaliyetler yürütmesinde Asur'un içinde bulunduğu buhranlı dönemin Asur dış politikasına olumsuz yansıması etkili olmuştur (Ceylan ve Ceylan, 2016, s. 22).

Argişti II'den sonra yerine geçen Rusa II (MÖ 685-645) babasının uyguladığı iç ve dış politikaları geliştirerek devam ettirmiştir. Urartu imar faaliyetlerinin yoğun olduğu bu dönemde iskan politikasına da ayrı bir önem vermiştir (Erzen, 1992, s. 37). Kafkas geçitlerini (Daryal ve Derbent geçitleri) aşarak dalgalar halinde Ön Asya dünyasına yayılan Kimmer ve İskit toplulukları dönemin Ön Asya devletleri için büyük bir tehdit konumundadırlar. Bu tehdit dalgası en başta Kafkaslara sınırı olan Urartu Devletini etkisi altına almıştır (Özgül ve Ceylan, 2017, s. 37-38; Özgül, 2015, s.170). Rusa II bu konar göçer toplulukların yıkıc1 etkisinden kurtulmak adına farklı politikalar ortaya koymuştur. Öncelikle Gümrü (İşkigulu) bölgesinde bulunan İskit halkları Kuzeybatı İran Bölgesi’ne yerleştirilmişlerdir. Kimmerler ile olan mücadelelere son verilerek Manna Ülkesine yerleşmelerine izin verilmiştir (Ceylan ve Ceylan, 2016, s. 22; Çilingiroğlu, 1983, s. 317). Asur Devleti açısından da büyük bir tehlike konumunda olan bu göçebe topluluklar Asur ve Urartu arasında nadir görülen bir saldırmazlık anlaşmasının yapılmasına da neden olmuştur (Ceylan, 1994, s. 212). Göçebe topluluklara karşı çeşitli politikalar geliştiren Asur kimi zaman mücadele kimi zaman anlaşma yolunu seçmiştir. Fakat bu buhranlı dönemde ayrıca İran'da gelişmekte olan Med topluluklarının Asur'a karşı cephe alıp Babil ve İskit güçleri ile ittifak yapması Asur’u çok zor bir duruma düşürmüştür. Bu durum ortak düşmanlara karşı Asur ve Urartu yakınlaşmasının da temel sebebidir. Son zamanlarında iyice zayıf duruma düşen Asur Devleti ortak düşmanların etkisiyle kısa bir süre sonra tarih sahnesinden silinecektir (ARAB II, 1927, s. 871; Dumlu, 2015, s. 50; Tarhan, 1972, s. 182 vd.).

Urartu'nun sıkıntı içinde olduğu bu dönemde başa Sarduri III (MÖ 645-635) geçmiştir. Babası Rusa II'nin faaliyetlerine devam eden bu kral ortak düşmanlara karşı ittifak için Asur sarayına elçiler 
göndermiştir. Asur ile kurulan bu karşılıklı dostluk ilişkilerine rağmen Ön Asya’nın bu iki büyük gücü içinde bulundukları zor durumdan kurtulamayarak tarih sahnesinden silinmişlerdir. Bu iki büyük gücün yok olmasından sonra Kuzeybatı İran topraklarında Med hakimiyeti başlamışıı (ARAB II, 1927, s. 871; Ceylan ve Ceylan, 2016, s. 24; Çilingiroğlu, 1994, s. 110 vd.).

\section{Urartu Yazıt Türleri ve İçeriği}

Urartu yazıtları incelendiğinde kaya yazıtları, taş steller ve mimari ile entegre olmuş yazıtlı taş bloklar Urartu çivi yazısının en çok kullanıldığı yazıt türleridir. Urartu krallığının hakim olduğu coğrafi saha da genellikle volkanik oluşumlu bazalt ve türlerinin yaygın olması nedeniyle metinlerin yazıldığı taş yüzeylerde daha çok bazalt kullanılmışır. Bazalıı yanında daha az olmakla birlikte kireç taşı kullanımı da vardır. Urartu çivi yazılı belgelerinin toplamı yaklaşık olarak 1700'ün üzerindedir. Bu belgeler içerisinde taş yazıtlar içerik bakımından en zengin bölümü oluşturmakta olup 400 civarındadır. Urartu'da kullanılan diğer bir yazı malzemesi kil tabletlerdir. Urartu döneminde yoğun kullanılan fakat günümüzde sadece 30'un üzerinde bulunan bu tabletler, ekonomik işlerle ilgili malzeme listesi belgeleri ve merkezden valilere gönderilen kral talimatlarını içeren mektuplar şeklindedir. Bunların dışında bir-iki satırlık yazıtlar vardır. Bu yazıtların bir bölümünü mühür ve mühür baskıları, tunçtan yapılmış at alınlı̆̆, araba oku süslemesi, göz siperliği, boyunduruk süsleri, dizgin diskleri, çıngırak gibi araba koşum takımlarının parçalanı, kalkanlar, miğferler, ok uçlanı, kılıç kınları gibi askeri amaçlı nesneler, kaplar, bazıları gümüş olan bakraçlar, şamdanlar gibi ev eşyaları, kemer gibi giyim eşyaları ve adak amacıyla yapılmış az sayıda tunç halka oluşturmaktadır (Çilingiroğlu, 1997, s. 149; Dinçol ve Dinçol, 2003, s. 121-124; Payne, 2006, s. 2 vd.; Salvini, 2006, s. 206 vd.).

Urartu yazıtları, türü bakımından zafer yazıtları, adak yazıtları, yap1 yazıtları, kanal yazıtları, depo yazıtları ve lanet yazıtları gibi türlere ayrllır (Ceylan ve Ceylan, 2015, s. 12). Yazıt türlerine bakıldığında bazıları yıllık şeklinde olup kralların zaferlerini anlatmaktadır. Bu yazıtlara en çok İşpuni-Menua, Menua, Argişti I ve Sarduri II dönemlerinde rastlanmaktadır. Diğer bir yazıt türü inşa yazıtlarıdır. Bu yazıt türüne Urartu krallı̆ı̆nın bütün dönemlerinde rastlanmakla birlikte en fazla Menua Dönemi’nde görülür. İnşa yazıtlarının bazılarında mimari yapının hangi kral tarafından yaptırıldığı kaydedilir. Bazılarında yazıtı tahrip edenlere karşı bir lanet dileği bulunur. Bazılarında ise tanrılara sunulan kurbanlar sıralanır ve tanrılardan kralı koruması istenir. Bu yazıtlarda en çok sitelin kendisi, tanrı kapıs1, kanal, tahıl deposu, kale ve bina gibi konulara yer verilir. Bu konulardan ayrı olarak susi, tapınak, grup halindeki bağ, bahçe ve tarlalar, burç, barzudibiduni, göl, tarmanili, sirsini, tulurini ve ormanlar'a ise daha az yer verildiği görülür. Sadece Menua Dönemi'ne ait ola yazıtlarda geçen barzudibiduni, sirsini, tulurini ve tarmanili gibi yapıların işlevleri henüz kesin olarak belirlenememiştir (Ceylan ve Ceylan, 2015, s. 12; Payne, 2006, s. 4 vd.). Urartu yazıtlarında kullanılan dil incelendiğinde genellikle klişeleşmiş ifadelerden oluşan resmi bir dil kullanıldığı görülür. $\mathrm{Bu}$ sebeple Urartu dilinin kelime dağarcığı ve dilbilgisi kuralları hakkındaki bilgilerimiz bunlarla sınırlı kalmaktadır (Dinçol ve Dinçol, 2003, s.120).

Urartu çivi yazılı belgeleri içerisinde yer alan savaş ve propaganda metinleri ayrı bir önem arz etmektedir. Bu metinlerde geçen propaganda ifadeleri dönemin Ön Asya'sında hakim olan başta siyasi ve dini olmak üzere kültürel, ekonomik ve bunun gibi özellikleri Urartu krallarının dilinden bize aktarır. Bu dil propaganda içerikli bir dil olup Urartu krallarının siyasi ve dini gücü birleştirerek topluma nasıl yön verdiklerini ortaya koyar. Bu dil yeri geldiğinde muhaliflere karşı bir bıçak gibi keskin, yeri geldiğinde müttefiklere karşı bağışlayıcı, yeri geldiğinde ise tanrıların nazarında bağışlanmak ve tanrıların desteğini almak isteyen edebi motifler içeren diplomatik bir dildir.

\section{Kuzeybatı İran'daki Urartu Yazıtlarındaki Savaş ve Propaganda İfadeleri}

Urartu Devletinin Kuzeybatı İran'daki varlığının göstergesi olan birçok yazıt tespit edilmiştir. Urartu krallık ideolojisini yansıtan bu yazıtlar savaş ve propaganda ifadesi olarak değerlendirebileceğimiz içeriklere sahiptir. Savaş ve propaganda ifadeleri bakımından büyük oranda benzerlik gösteren bu yazıtlardan belli başlı olanları şu şekildedir. 
Tablo 1. Kuzeybatı Iran'da Tespit Edilen Belli Başl Urartu Yąutlarn

\begin{tabular}{|c|c|c|c|c|c|}
\hline Kral & Yaz1t & $\begin{array}{c}\text { Yazıtın Günümüzdeki } \\
\text { Konumu }\end{array}$ & Kral & Yaz1t & $\begin{array}{c}\text { Yazıtın Günümüzdeki } \\
\text { Konumu }\end{array}$ \\
\hline $\begin{array}{l}\text { İsspuini- } \\
\text { Menua }\end{array}$ & Kalatgah & Pensylvania Metropolitan Müzesi & Rusa I & $\begin{array}{l}\text { Mergeh } \\
\text { Karvan }\end{array}$ & $\begin{array}{l}\text { Kelişin Geçidine } 7 \text { km Uzaklıkta } \\
\text { Bir Köyde }\end{array}$ \\
\hline $\begin{array}{l}\text { İsspuini- } \\
\text { Menua }\end{array}$ & Kelişin & Urmiye Müzesi & Rusa I & Movana & Urmiye Müzesi \\
\hline Menua & Ain-e Rum & $\begin{array}{l}\text { Rezaiyeh Kentinin } 54 \mathrm{~km} \text { güneyi, } \\
\text { Uşnaviye Yolu Üzeri, Anakaya } \\
\text { Üzerinde }\end{array}$ & Argişti II & Naşteban & $\begin{array}{l}\text { Erdebil'in } 60 \mathrm{~km} \text { Güneybatısında } \\
\text { Naşteban Kalesi Anakaya } \\
\text { Üzerinde }\end{array}$ \\
\hline Menua & Uşnu & Tahran Arkeoloji Müzesi & Argişti II & Razlık & $\begin{array}{l}\text { Sarab Kentinin } 15 \mathrm{~km} \text { Kuzeyinde } \\
\text { Anakaya Üzerinde }\end{array}$ \\
\hline Menua & Taştepe & British Müzesi & Argişti II & Shisheh & $\begin{array}{l}\text { Khoy Ovasındaki Khoy } \\
\text { Köyünün Sırtındaki Kayalıklarda }\end{array}$ \\
\hline Argişti I & Javankale & $\begin{array}{l}\text { Ajabşir Şehrinin } 8 \mathrm{~km} \text { Uzağında } \\
\text { Bir Tepe Başındaki Kayalıklarda }\end{array}$ & Rusa II & $\begin{array}{l}\text { Maku } \\
\text { Kasabası } \\
\text { Harebeleri }\end{array}$ & $\begin{array}{l}\text { Maku Kasabasının } 16 \mathrm{~km} \\
\text { Güneybatısında Taş Levha } \\
\text { Üzerinde }\end{array}$ \\
\hline Sarduri II & Sı̆̆ındıl & $\begin{array}{lrr}\text { Ahar'ın } & 35 \mathrm{~km} \text { Kuzeybatısında } \\
\text { Suğıldıl } & \text { Kalesinde Anakaya } \\
\text { Üzerinde } & & \\
\end{array}$ & Rusa II & Bastam & Eski İran Müzesi \\
\hline Rusa I & $\begin{array}{l}\text { Mahmud } \\
\text { Abad }\end{array}$ & Urmiye Müzesi & & & \\
\hline
\end{tabular}

Kelişin Yazıtı: Uşnaviye (İran)-Revanduz (Irak) arasındaki geçit üzerinde, tam olarak bugünkü İranIrak sınırında tespit edilmiştir. İșpuini-Menua dönemlerine M.Ö. IX. yüzyll sonuna tarihlendirilmektedir. Büyük bir stel üzerinde, bir yüzü Asurca, diğer yüzü Urartuca olmak üzere çift dilli bir yazıttır. Günümüzde Urmiye Müzesi’nde yer alan yazıt türü bakımından bir yapı yazıtıdır. Fakat içerisinde geçen adak ve lanetleme ifadeleri nedeniyle adak ve lanet yazıtı özelliği de göstermektedir. Çift yüzlü olan yazıtın iki tarafındaki çeşitli bölümlerde tahribat görülmektedir. Yazıtta geçen belli başlı propaganda ifadeleri şu şekildedir:

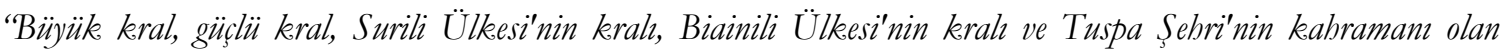
Sarduri oğlu İspuini ve İspuini oğlu Minua...”, “... hayatımızın sevinci olan efendi tanr Haldi...”, "Sarduri oğlu İspuini,

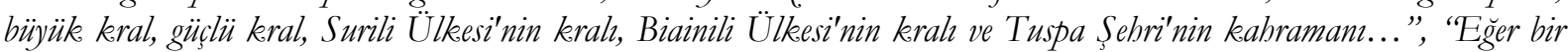
kimse Ardini Şebri'nde bulunursa ve biri başkasinn büyükbas hayvam Haldi kapısindan götürmeye kalktiğm duyarsa (ve bunu saklarsa), tanr Haldi, soyunu dünya üzerinden yok etsin. Her kim bu steli bu yerden sökerse, her kim suc islerse veya her kim bir baskasina bunlar yapturrsa ve "Gel, tabrip et!" derse, tann Haldi, tanr Teiseba, tann Sivini ve Ardini Sebri'nin (bütün) tanrlar, soyunu yeryüzü̈nden yok etsinler." (Belck- Lehmann, 1892, s. 122-156; Benedict, 1961, s. 359-385; Ceylan, 2015c, s. 257-258; CICh, 1928-35, no. 12, tab. 3; CTU, 2008a, no. A3-11; Edmonds, 1966, s. 159-163; Götze, 1930, s. 99-128; HCHl, 1953-57, no. 9; Payne, 2006, s. 55-56; Sandalgian, 1900, no. 2; 1935, s. 132-160; Sayce, 1882, s. 663-664, no. 56; 1893, s. 32; 1894, s. 691-692; 1901, s. 653-656; 1906, s. 611-612; Tseretheli, 1933, s. 1-49; 1935, s. 85; 1951, s. 205-208; 1955, s. 131-140; UKN, 1960a, no. 19).

Mergeh Karvan Yazıtı: Rusa I Dönemi’ne tarihlendirilen yazıt Kelişin Geçidine 7 km. uzaklıkta ki bir köyde yer almaktadır. İki dilli yazıttır. Ön ve sol yüzünde Asurca, arka ve sağ yüzünde ise Urartuca yazılmıstır. Keli Gavur yazıtının kopyasıdır. Yazıt bir sefer yazıtı olmasına rağmen imar faaliyetlerinden ve tanrilara sunulan adaklardan da bahsetmektedir. Yazıtın Urartuca olan yüzlerinde tahribat fazla iken Asurca olan yüzleri daha az tahribat görmüştür. Yazıtta geçen propaganda ifadeleri şöyledir:

“...tanr Haldi'nin buyruğuyla ve Rusa'nm başarllhluğ için...”, “...Urzana'yı krali atalarmm yü̈ksek tabtlar üzerine oturttum ... Urzana, tanrlarn önünde, tanrlarn tapınağgnda, benim bu₹urumda kurbanlar sundu. Aym zamanda kapıda efendi tanr Haldi'ye bir tapınak ve onun ilahi gücüne bir konut yaptturdim...”, “...tanr Haldi'nin buyruğuyla ben Rusa, Asur Ülkesi'nin șebirleri ile karșı karșsya geldim (ve onlari) yerle bir ettim. Bundan sonra Urzana elimden tuttu. Ona baktım ...onu krallhk (sürecek) tabtnna oturttum. Ardini Sebri'nin balke (bu törende)ydiler....", "...Tanr Haldi'nin bizmetçisi ve halken sadık çobanı...", “...Tanrlar bana sevinc dolu u₹un günler verdi ve sevinçli günler ...”, (Ceylan, 2015c, s. 262-263; Kleiss, 1977, s. 81 vd.; Salvini, 1984, s. 79 vd. no. 7.2; Salvini, 1986, s. 155 vd.; Payne, 2008, s. 265).

Mahmud Abad Yazıtı: Rezaiyeh'in 28 km. güneyi, Kukia Köyü'nün 2 km. batısındaki tepe üzerinde tespit edilmiştir. Burada Rusa I Dönemi'ne ait taş yazıt parçasına rastlanmıştır. Günümüzde Urmiye 
Müzesi'nde yer alan yazıt hem bir yap1 hem de bir adak yazıtı özelliği göstermektedir. Yazıt okunabilirlik açısından iyi durumdadır ve fazla bir tahribat görmemiştir. Yazıtta şu ifadeler yer almaktadır:

"Sarduri oğlu Rusa der ki: Burada kurban kurallann buyurdum...”, “...Rusa, tanr Şebitu'nun hižmetçisi ve tanr Sebitu karşısmda vasal(?)dır. Rusa her zaman onun vasalı(?) olsun. Sarduri oğlu Rusa der ki: Her kim bu yaz̨tı tabrip ederse, güneş ısı̆ğından...” (Ceylan, 2015c, s. 261; Diakonof, 1988, s. 133-180; 1989, s. 90, no. 4; Payne, 2006, s. 271; Salvini, 1977, s. 125-136; 1984, s. 77 vd.; 1986, s. 155 vd.).

Sığındıl Yazıtı: 2013 yılında A. Ceylan başkanlığında Kuzeybatı İran Yüzey Araştırmaları kapsamında Verzegan Bölgesi’ndeki Sığındıl Yazıtı üzerinde de incelemelerde bulunduk. Bu yazıt İran Doğu Azerbaycan'ında yer alan Suğındıl, Ahar'ın 35 km. kuzeybatısında ve Verzegan'ın 5 km. doğusunda yer almaktadır. Sarduri II Dönemi’ne tarihlendirilen yazıt türü bakımından bir zafer yazıtıdır. Yazıt kısmi tahribat görmesine rağmen okunabilir durumdadır. Sığındıl Kalesinde anakaya üzerine inşa edilmiş yazıtta şu ifadeler yer almaktadır:

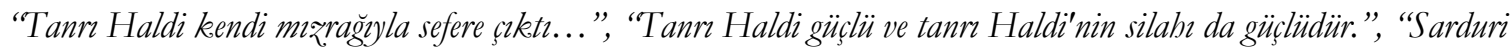
der ki: Bir gün içinde 21 kale yendim ve 45 sebir ele geçirdim.”, "Sarduri, güçlü kral, büyüke kral, ülkelerin kral, Biainili Ülkesi'nin kralı ve Tušpa Şehri'nin kahramanıdır.”, (Ceylan, 2015c, s. 259; Melikişvili, 1960a, s. 3 vd.; 1960 b, s. 29-37; 1960c, s. 59 vd.; Salvini, 1981, s. 69 vd.; Salvini, 1982, s. 97 vd.; Payne, 2006, s. 240).

Razlık Yazıtı: Sarab kentinin 15 km. kuzeyinde yer alır. Argišti II Dönemi’ne aittir (MÖ VIII. yüzy1l sonu - MÖ VII. yüzyılın başı). Anakaya üzerindedir. Yazıt zafer yazıtı türündedir. Yazıtın kimi kısımları tahribat görmüştür. Yazıtta yer alan propaganda ifadeleri şu şekildedir.

"Tanr Haldi'nin kudretiyle Rusa oğlu Argišti der ki:", "Ele geçirdiğim ülkeleri haraç (ödemeleri koşulu) ile

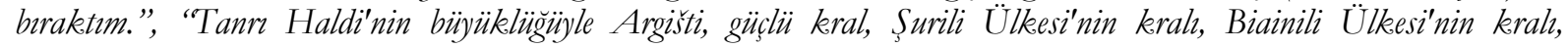

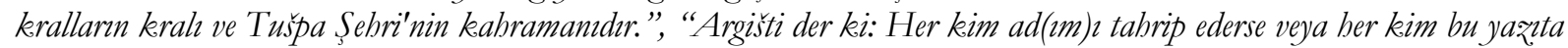
karş suc işlerse, tanr Haldi, tanr Teišeba, tanr Şivini (ve bütün) tanrlar onu güneş ısı̆ğindan yoksun etsinler." (Benedict, 1965, s. 35 vd. no. 2; Ceylan, 2015c, s. 263; CTU, 2008a, no. A11-4; Payne, 2006, s. 275 ; A. Salvini ve M. Slavini, 1999, s. 17).

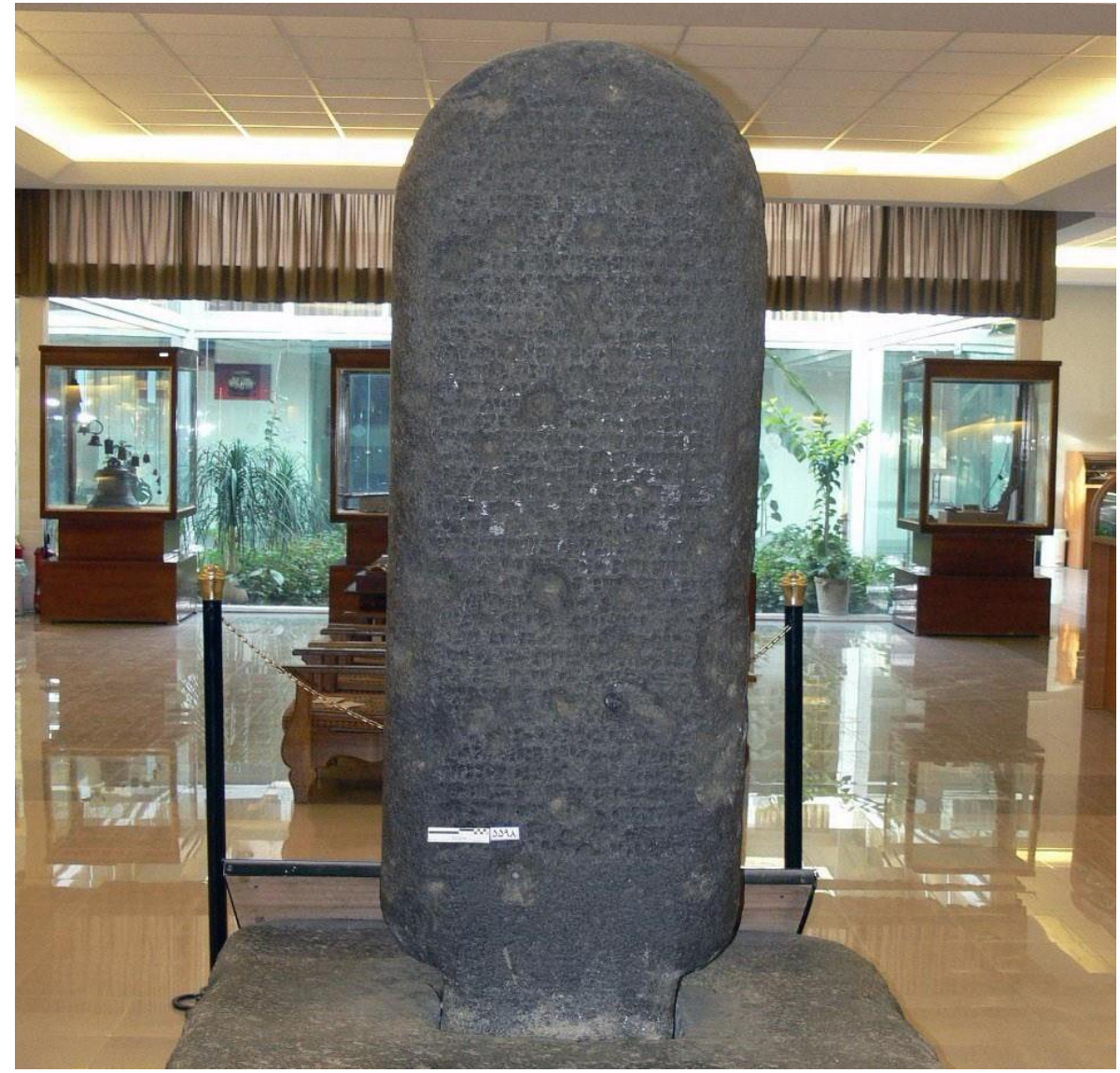

Foto 1. Kelişin Yar̨t 


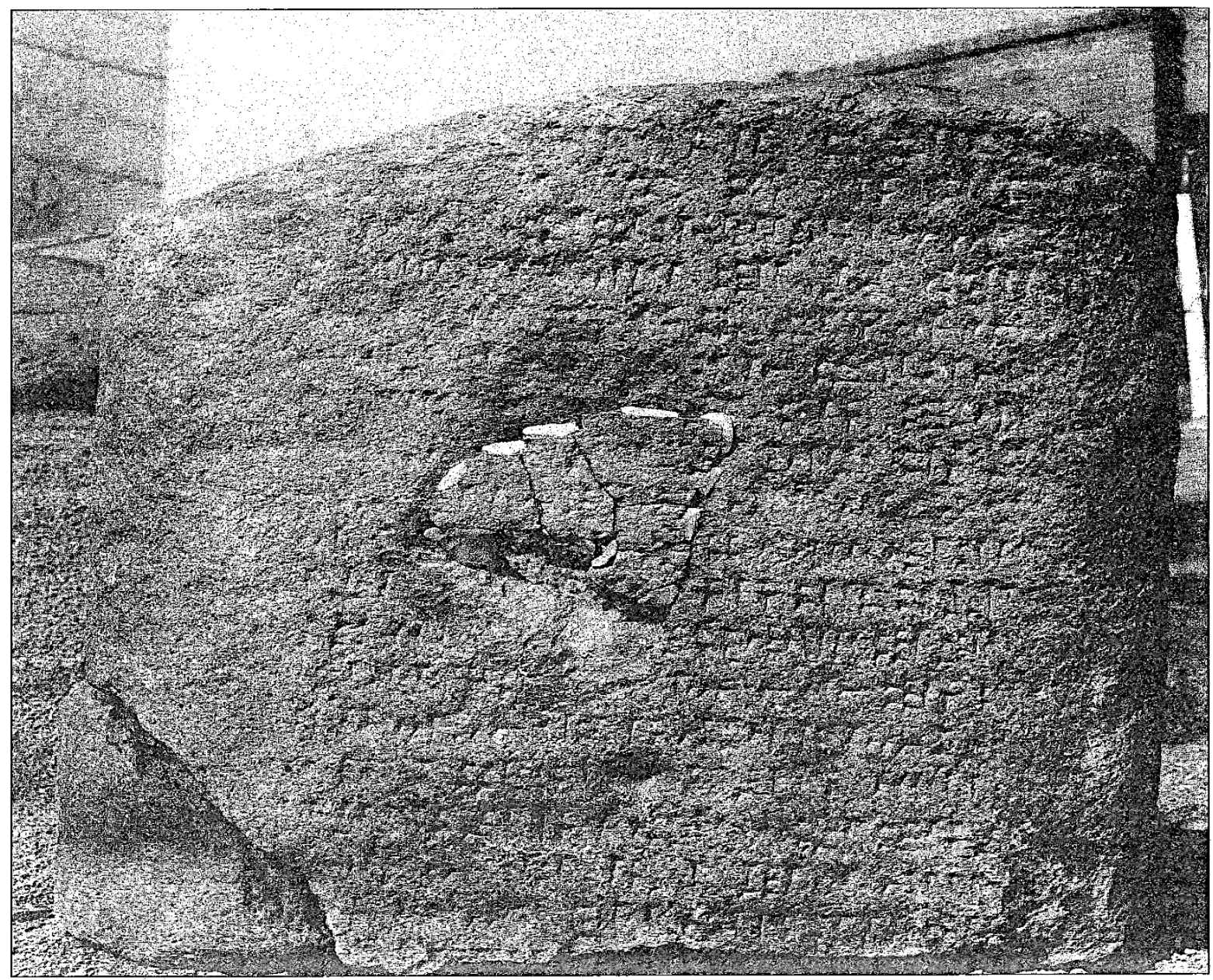

Foto 2. Mergeh Karvan Yartı (CTU, 2008b, s. 312)

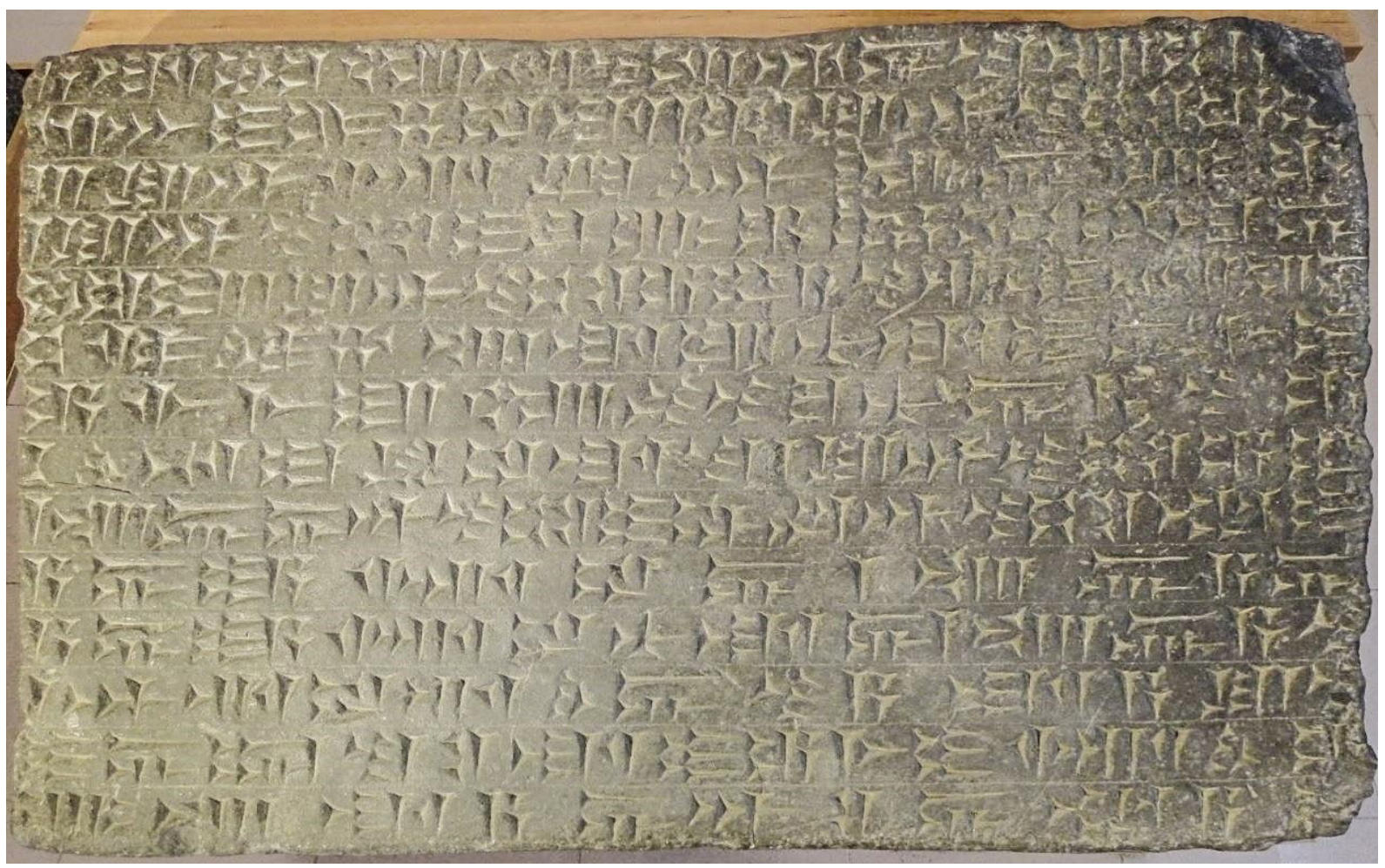

Foto 3. Mahmud Abad Yazitı 
CEYLAN ve ÇİFTÇİ

Kuzeybatı Iran'daki Urartu Yazıtlarındaki Savaş ve Propaganda İfadeleri

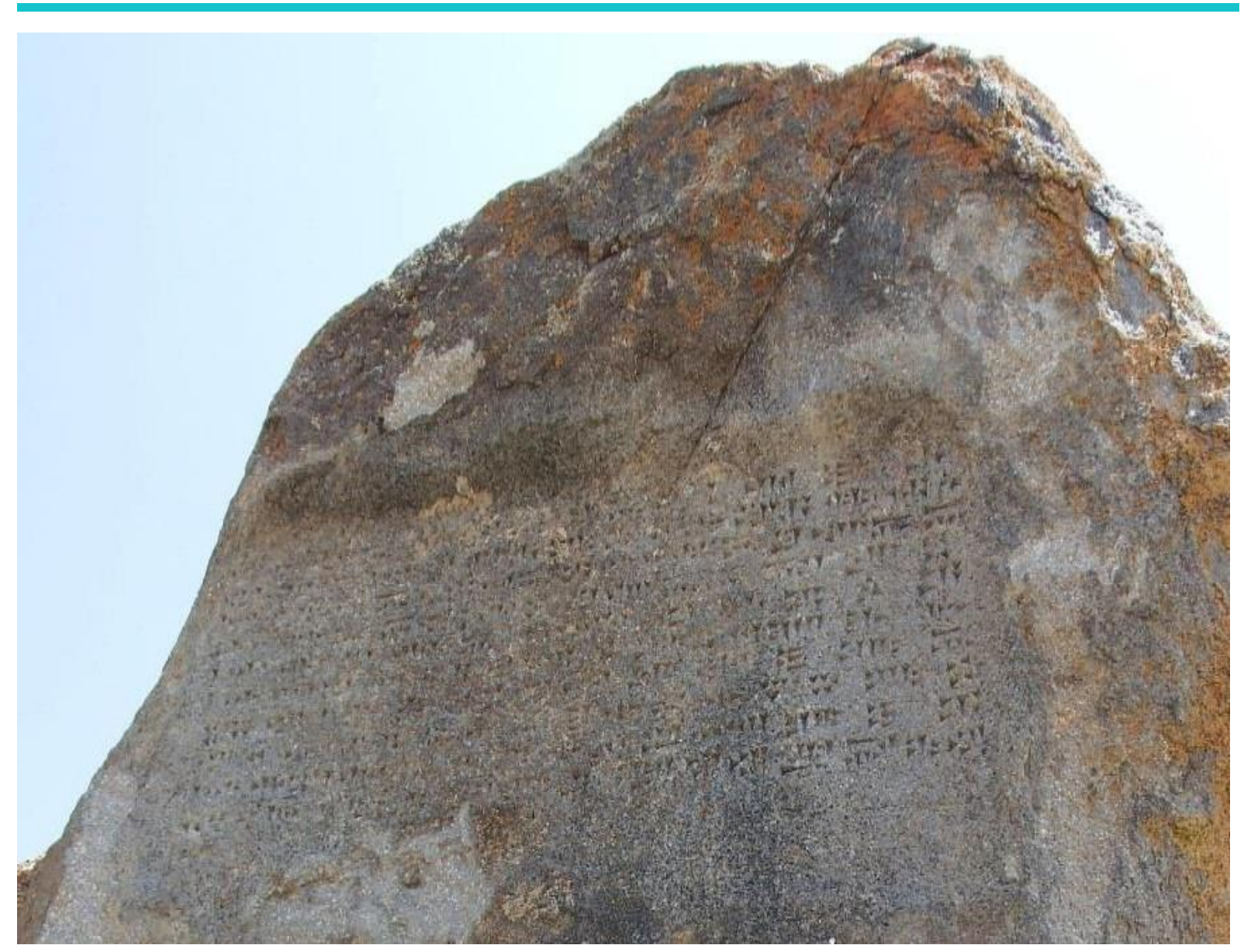

Foto 4. Siğgndll Yaz̨tl

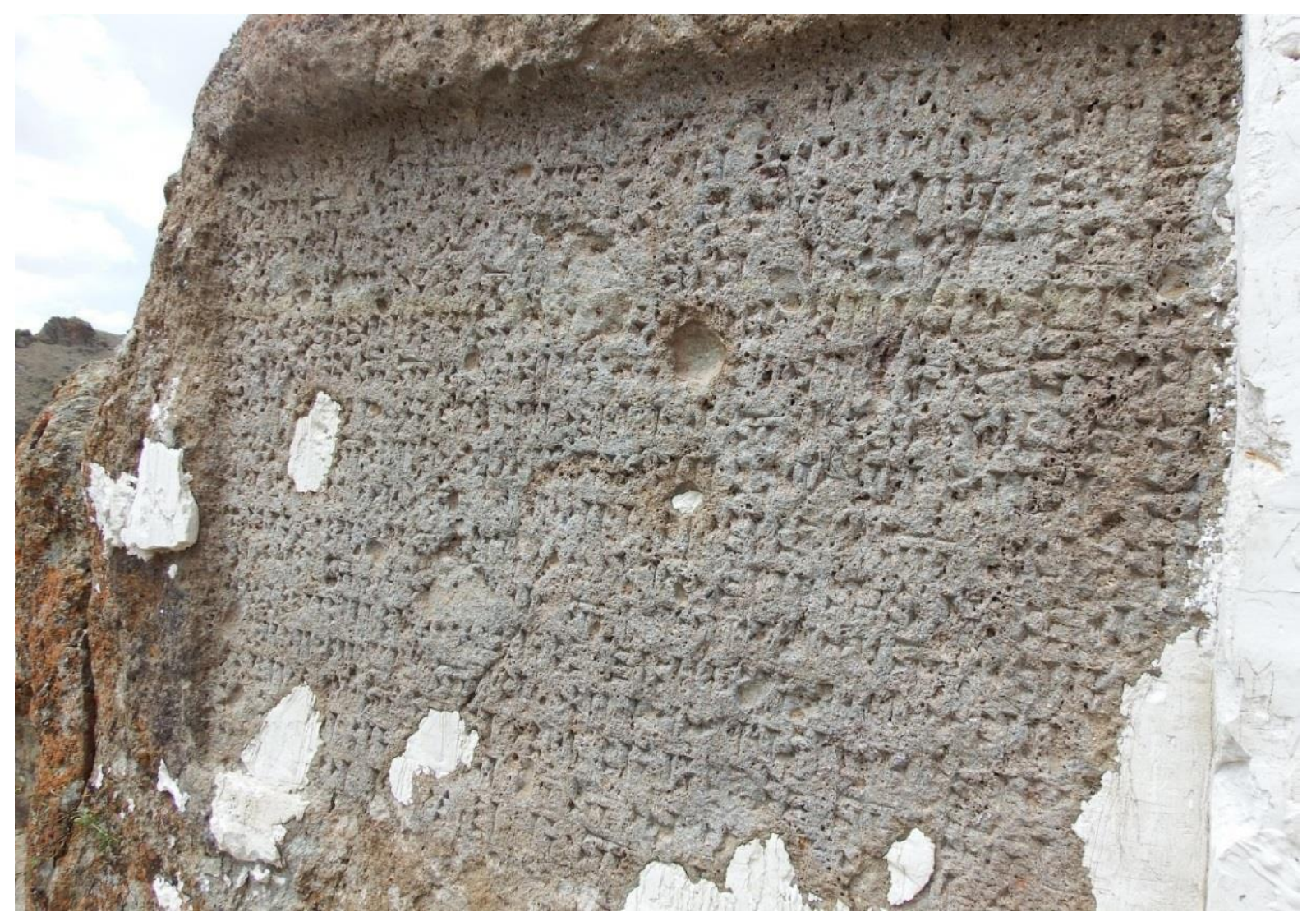

Foto 5. Razlık Yazıtı 


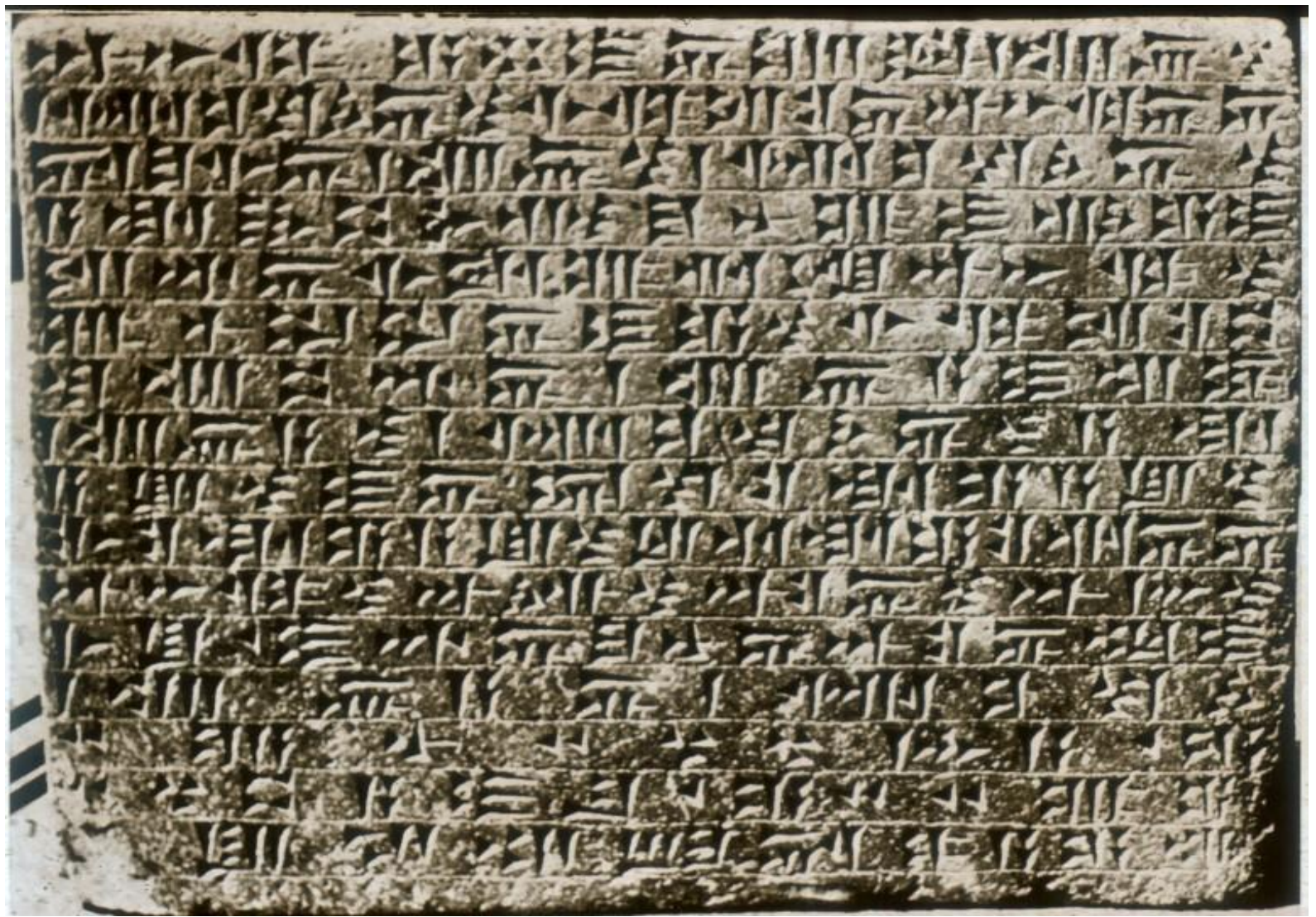

Foto 6. Bastam Yą!tı

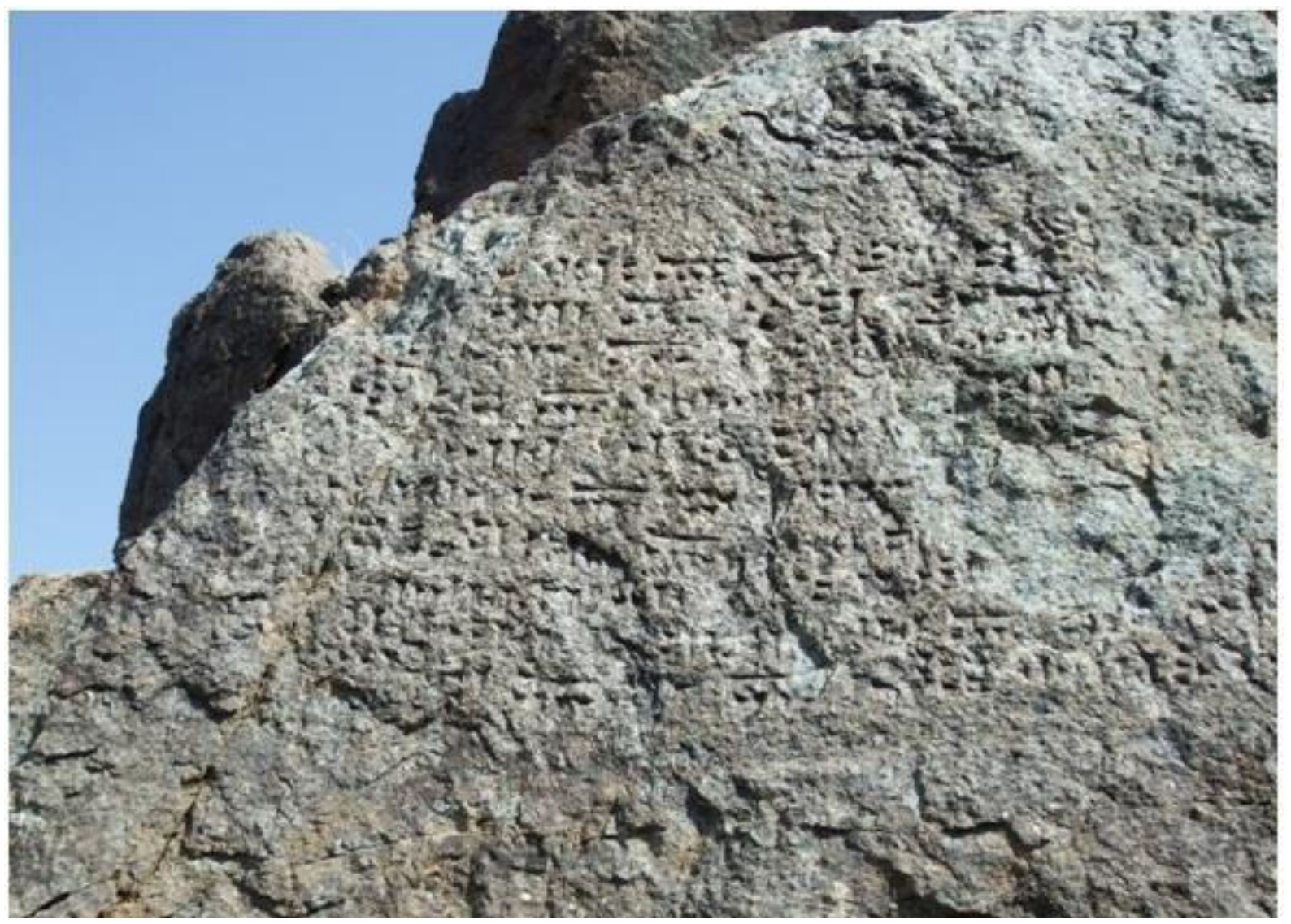

Foto 7. Javankale Yaztt 
CEYLAN ve ÇİFTÇİ

Kuzeybatı Iran'daki Urartu Yazıtlarındaki Savaş ve Propaganda Ifadeleri

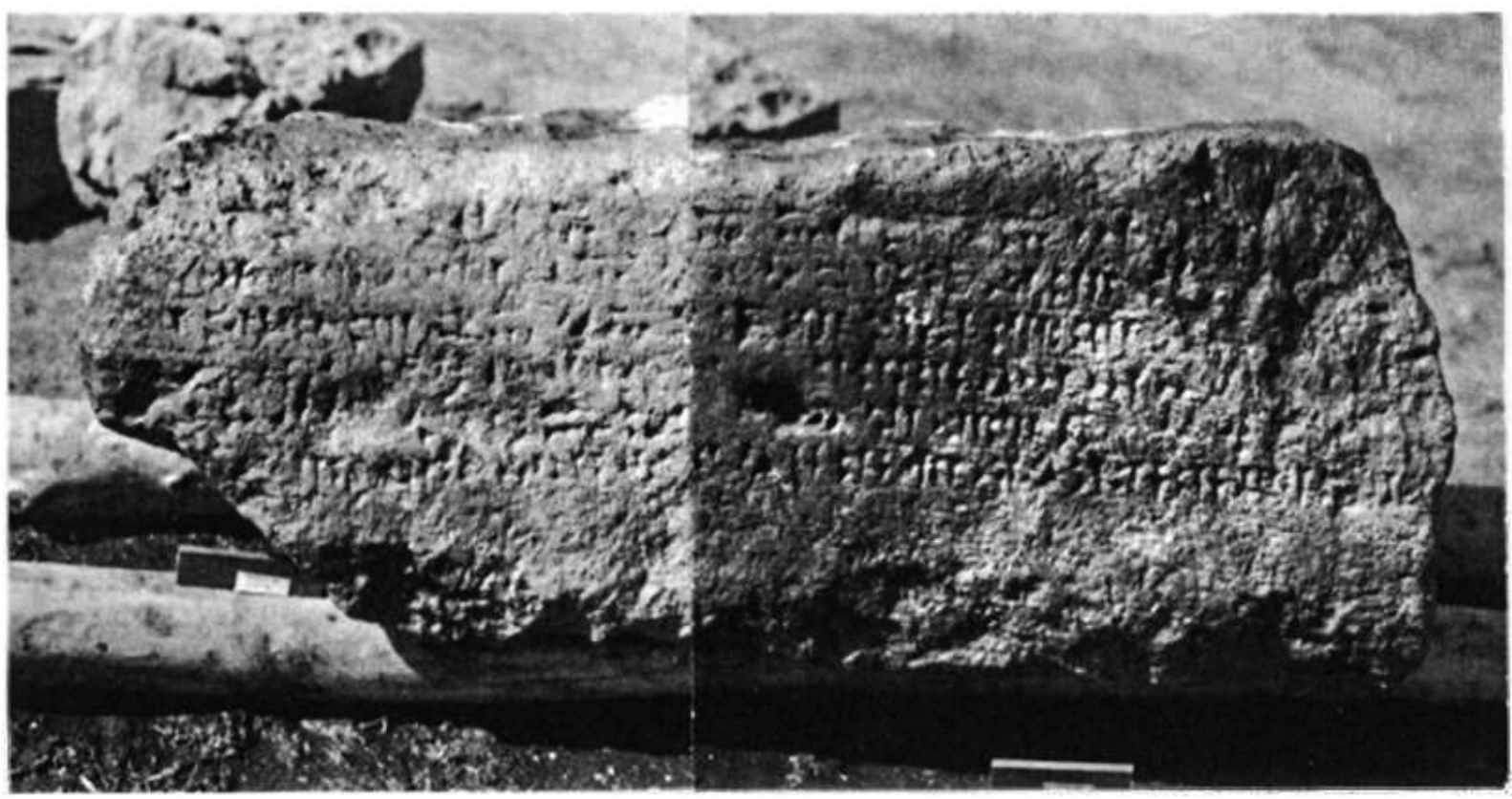

Foto 8. Kalatgah Yazıtı

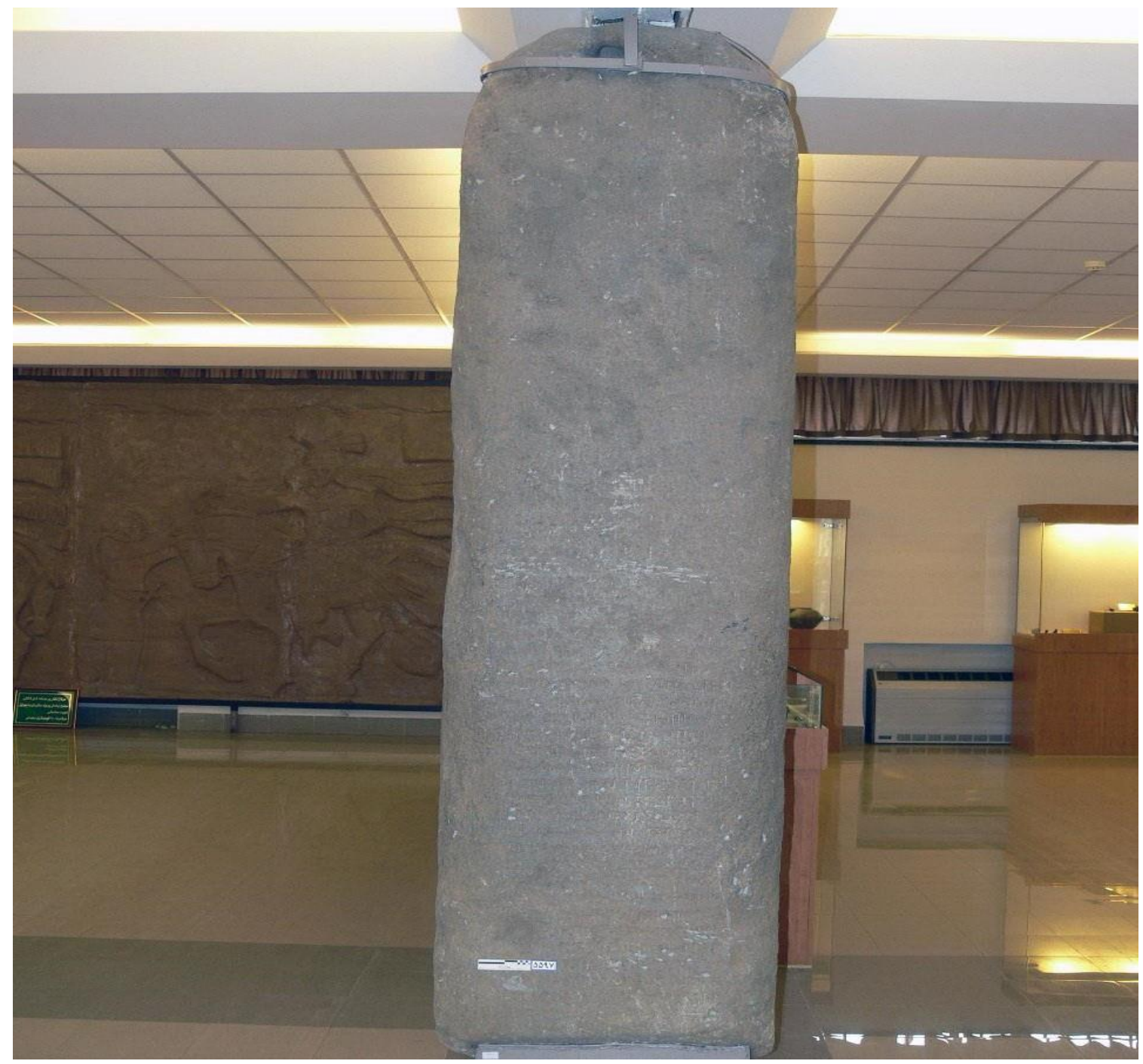

Foto 9. Movana Yazıtı 


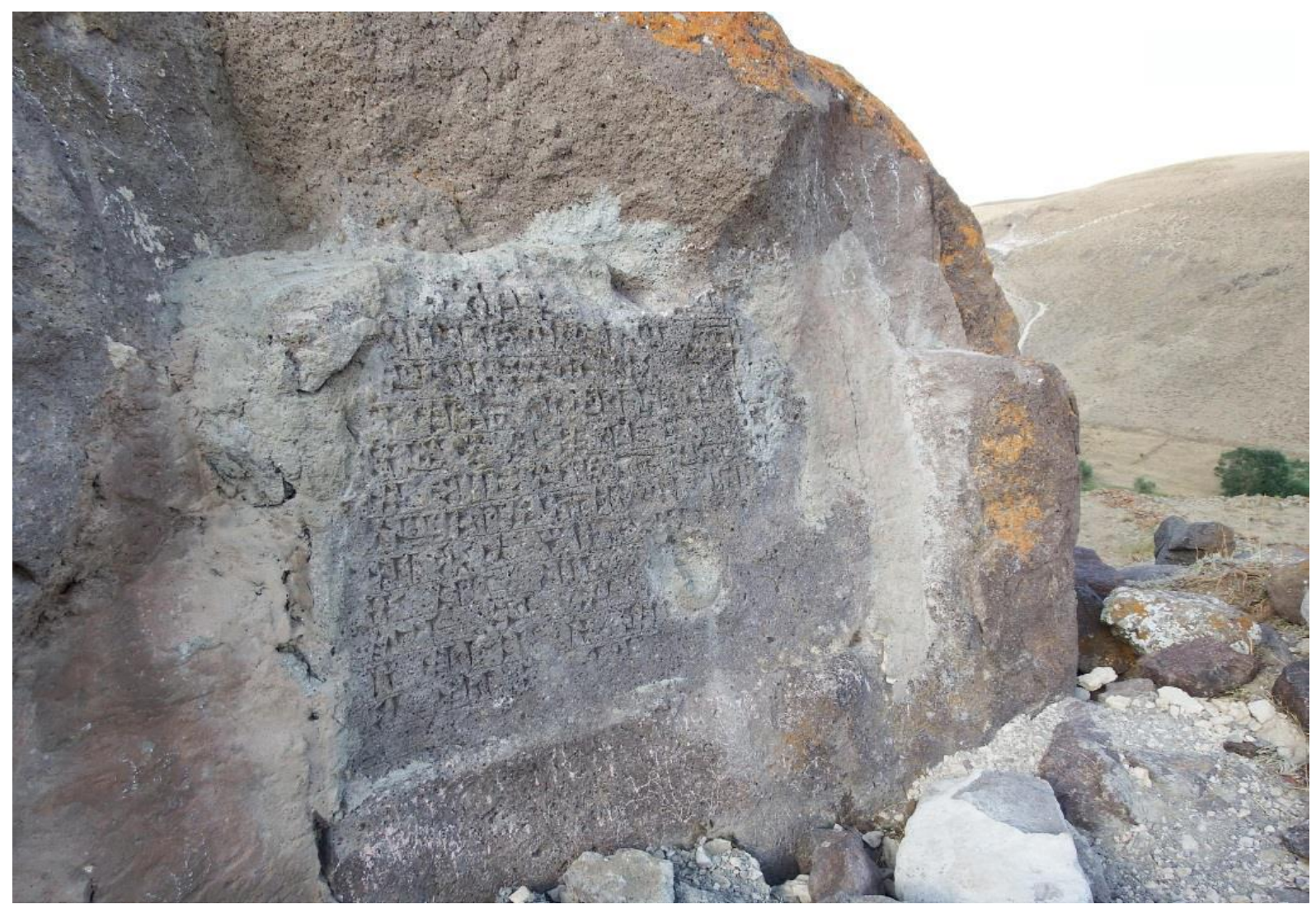

Foto 10. Naşteban Yaz̨tı

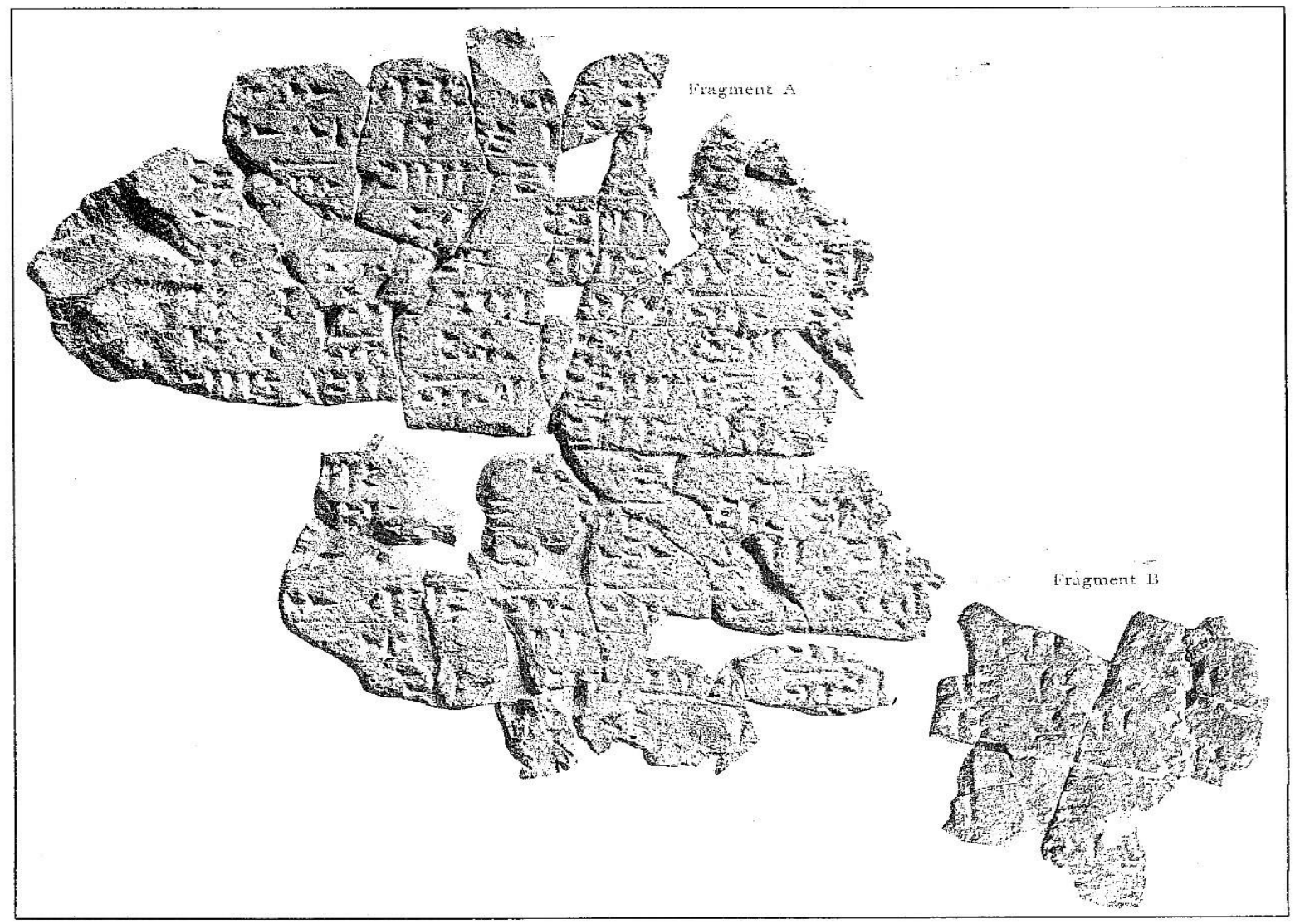

Foto 11. Tasstepe Yazıt (CTU, 2008b, s.123) 


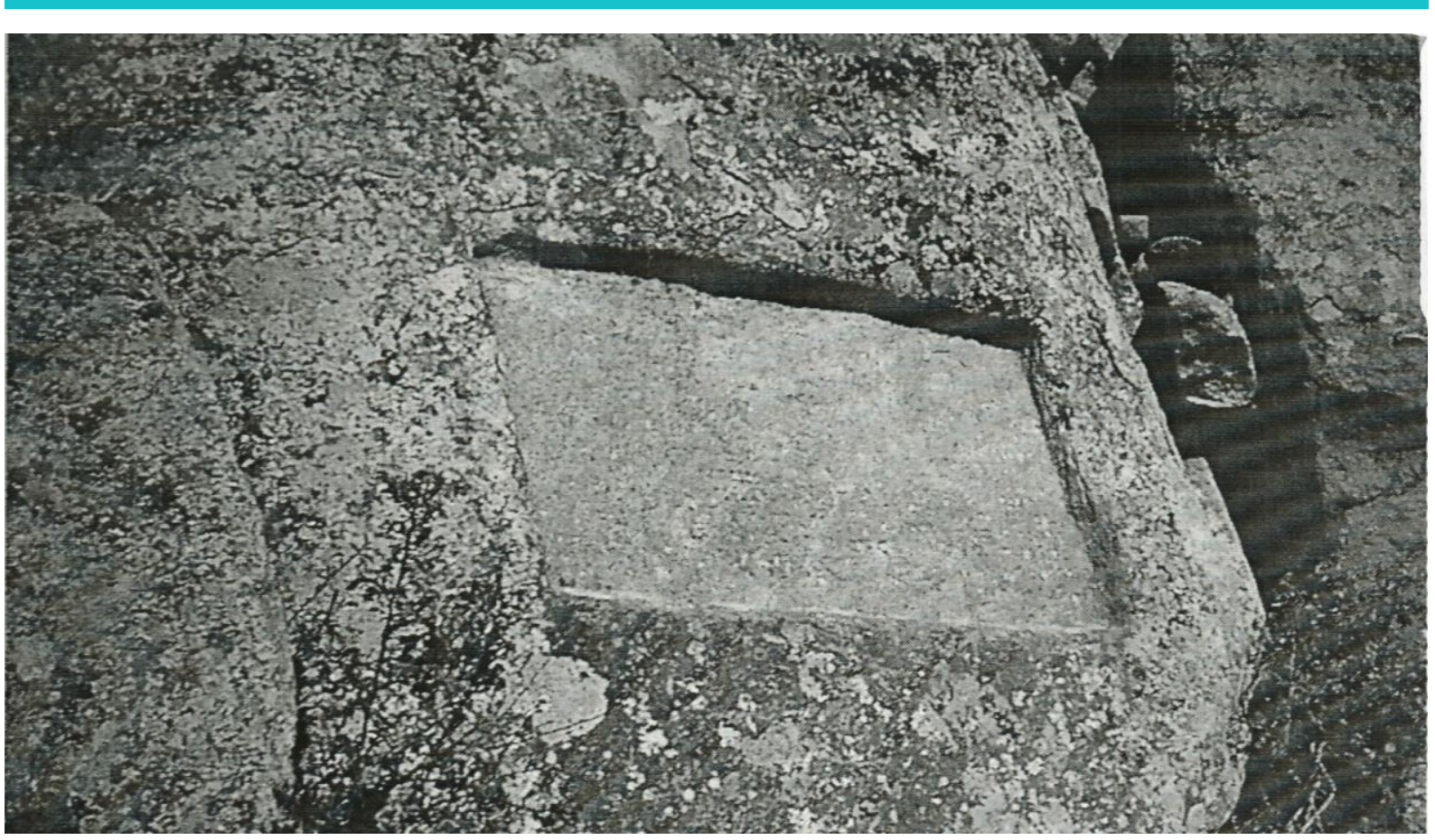

Foto 12. Shisheh Yazit

Kuzeybatı İran Urartu yazıtlarında yer alan dil incelendiğinde genellikle klişe ifadelerin kullanıldığı görülür. Resmi içerikli olan bu ifade tarzı Urartu devlet dilinin bir göstergesidir. Urartu krallarının kullandığı bu ifade tarzı dönemin Ön Asya coğrafyasının farklı bölgelerinde hüküm süren devlet kralları tarafindan da kullanılmıştır. Urartu yazıtlarında kralların kullandığ1 güç unvanları olan "büyǚk kral, güçlü kral" gibi ifadeler, ülke ve ya ülkelerin tek hakimi olduğunu belirten vurgulamalar ve özellikle baş tanrı Haldi ile birlikte kralın ve babasının isminin birlikte geçtiği söylemler kralın din odaklı gücünü ve siyasi prestijini ortaya koymaktadır.

Eski Çağ Ön Asya dünyasının önemli güç odaklarından biri olan Asur imparatorluğu krallarından Sargon II (MÖ 722-705) ve Tukulti Ninurta II (MÖ 890-894) yazıtlarında "tanrlarn babasi, ülkelerin efendisi, efendilerin efendisi, bütün yeryüzü ve gökyü̈zünün efendisi” gibi unvanlar1 (Grayson, 1972, s. 164; ARAB II, 1927, s. 93; Poebel, 1942, s. 247 vd.) ve Pers imparatorluğu krallarından Darius I (MÖ 549-485) ve Kserkses (MÖ 486-465) yazıtlarında "büyük kral, krallarm kral, Perslerin, halklarn, ülkelerin krah, pek sok etnik kökene sahip topraklarn kral, bu büÿ̈̈k ve uzak dünyann kralı" gibi unvanlar kullanmışlardır (Basello, 2013, s. 137; Kuhrt, 2007, s. 141). Yine Hitit imparatorluğu krallarından Hattuşili III (MÖ 1275-1245) yazıtlarında 'Hatti ülkesinin kral, büyüle kral Murşili'nin oğlu, Hatti ülkesinin kral, büyü̈k kral Suppiluliuma'nn torunu, Kuşsar kralmin Hattusili soyundan Hatti ülkesinin kral, büyük kral, Tabama Hattusili.” gibi unvanlar kullanmıştır (Kuhrt, 2013, s. 339). Ön Asya krallarının yazıtlarında geçen bu unvanlar imparatorluk ideolojileri doğrultusunda kullanılmıştır. Meşruiyetlerini sağlam temellere oturtmak adına kullandıkları bu ifadelerin propaganda değeri yüksektir. Bu bakımdan Urartu yazıtlarında geçen propaganda ifadeleri ile benzerlik göstermektedir.

Urartu yazıtlarında geçen propaganda ifadeleri incelendiğinde birbirinden farklı konuların farklı bakış açılarıyla aktarıldığ görülür. Bu ifadeler göz önüne alındığında kral unvanlarının yanında kralın tanrının sadık hizmetçisi ve halkının lideri konumunda olduğunu ortaya koyan çoban kral benzetmeleri, tanrılar onuruna törenler yapılıp kurbanlar kesilmesi, mimari faaliyetlerin çeşitli aşamalarında tantıların lütfu ön plana alınarak törenler düzenlenmesi ve askeri seferler sonucu kazanılan zaferler anlatılırken mağlup olan kralın öldürülmesi veya affedilip haraca bağlanması etkili bir dil ile çokça işlenen konulardır. Bu konuların yanında ele geçirilen ülkeye yeni kral atanırken bunun Urartu kralının izniyle olması, sefer sırasında bir gün içinde birçok kale ve şehrin ele geçirilişinin abartılı bir şekilde anlatılması ve yazıtların sonunda kralın buyruklarının inkar edilmesi veya bu buyrukların yazılı olduğu yazıtların tahrip edilmesinin lanetlenmesi gibi konuları içeren ifadeler söylem gücü yüksek bir şekilde insan kitlelerine aktarılmak istenmiştir.

Urartu yazıtlarında yer alan bu ifadelerin benzerlerine Eski Çağ Ön Asya yazıtlarında da rastlamak mümkündür. Asur kralı Asurbanipal'in (MÖ 686-626) taç giyme törenine ait bir ilahide "Anu tacmı verdi. Illil tabtın verdi; Ninurta silahım verdi; Nergal aydınlk saltanatım verdi. Nusku damısmanlar gönderdi ve buzuruna 
cıkard, "Eline savas silahın verin, ona kara kafah insanlar verin ki gobanlar olarak onları gütsün!" ifadeleri geçer (Kuhrt, 2003, s. 170). Yine Babil hükümdar1 Hammurabi (MÖ 1810-1750) dönemindeki Hammurabi kanunlarının ön sözünde 'Mukadderatı tayin eden ulu tanr Enlil, Ea'non oğlu Marduk için, tanr korkusu olan ben Hammurabi'yi memlekete adaleti tecelli ettirmem için, insanlarn üzerinde günes gibi tecelli etmem için, insanlarn bedenini rahat ettirmem için, Anu ve Enlil adımı andllar. Enlilin çağırdĭg Hammurabi’yim ben" ifadeleri geçer (Tosun ve Yalvaç, 1989, s. 181-185). Bu ifadeler Urartu yazıtlarında olduğu gibi bu kralların tanrıların temsilcisi ve insanların yöneticisi olduğunu ortaya koyar (Kuhrt, 2003, s. 170).

Hitit Dönemi'ne ait KUB 25. 14 numaralı metinde bir hasat bayramı olan Nuntarriyasha ilgili olarak “O (kraliçe), Arinna'nn Güneş-Tannı̧a'sına şu şekilde kurban sunar: yedi kuzu, ikisi Walan[ni]’nin Arinna'nn Günes-Tanrısası'na; bir kuzu Nika[lmati]nin Arinna'nn Günes-Tannıç'sna,; bir kuұu Ašm[unikal]’in Arinna'nn

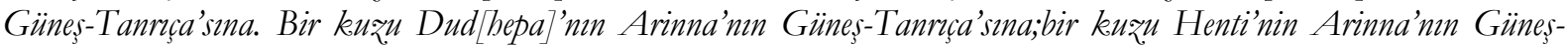

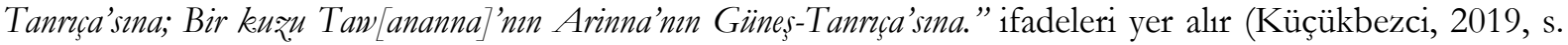
142). Urartu yazıtlarında da bahsedildiği gibi Hititler'de de tanrılar, kral, kraliçe ve ya kraliyet ailesinden olanlar için törenler yapllıp tanrılara kurbanlar verilirdi (Yiğit, 2003, s. 142; Yiğit, Özcan ve Kıymet, 2016, s. 201). Bu kurban törenleri farklı amaçlar doğrultusunda olmakla birlikte toplumsal birlik ve bütünlügü ön plana alan bir propaganda şekli niteliğindedir.

Pers kralı Darius I'in Nakş-i Rüstem yazıtında "Kral Dareios şöyle diyor: Aburamazda'nn inayetiyle Pers ülkesi dişında ele geçirdig̈zim ülkeler bunlar; onlara bükmettim; bana "baraç" getirdiler; benim söylediklerimi yerine getirdiler; Kanunum onlar bağladı..." ifadesi verilip devamında haraç alınan ülkeler sıralanmaktadır (Kuhrt, 2003, s. 395). Asur kralı Sargon II'nin meşhur sekizinci seferini anlatan metinlerde "Urartu'lu Ursa'nn 7 eyaletini ve 430 kentini tamamen ele geşirdim ve ülkesini barap ettim.” İfadesi geçmektedir (ARAB II, 1927, s. 99; Pınarcık, 2014, s. 51-52). Pers kralı Darius I'in yazıtında ele geçirilen ülkelerin haraca bağlanması ve Asur kralı Sargon II’ye ait olan yazıtta ele geçirilen yerlerin sayısının abartılı bir şekilde verilmesi bir güç gösterisi niteliğindedir. Urartu yazıtlarında da buna benzer ifadeler geçmektedir.

Urartu yazıtlarında bazı ifadeler beddua şeklindedir. Urartu yazıtlarının genellikle son bölümlerinde yer alıp kara propaganda şeklinde olan bu ifadelerin benzerlerine dönemin önde gelen krallıklarının yazıtlarında da rastlanmaktadır. Hitit imparatorluğu döneminde yapılan Kadeş antlaşması metninin bir bölümünde 'Ve Hatti Ülkesi kral Hattusili'nin oğlu, Hatti Ülkesi kralı Hattusili'den yullar sonra, babast Hattusili'nin (yerine) Hatti Ülkesi krah yapulsın. Ve eğer Hatti Ülkesi (insanlarn) ona karş̧ bir suç işslerse, sonra Amon "un sevgilisi (Ramses) yaya ve (arabali) savasscllar göndersin. Ve onlardan ög alsmlar." ifadeleri yer alır (Ceylan, 1991, s. 133-134; Karauğuz, 2002, s. 246). Hitit metninde geçen bu ifadeler Urartu metinlerinde olduğu gibi yapilmamasi gerekenleri sert bir dil ile ortaya koymaktadir.

Ön Aya krallarına ait yazıtlarda kralların propaganda faaliyetlerinden ayrı olarak düşman devletlerin propaganda mahiyetinde uyguladığı casusluk faaliyetlerinden de bahsedilmektedir. Eski Asur krallarından Şamşi-Adad'ın (MÖ 1815-1772) oğlu Yasmah-Adad'ın babasina yazdığ1 bir mektupta “Askerlerin ayaklanmasina kim neden oldu? İki asker! Bu iki adam korku yaratarak askerlerin ayaklanmasma neden oldu...(Simdi) bu adamlar zincirlediler ve Mari'ye götürdüler. Böyle bir ajan çok sayzda askerle gelmis olabilir" ifadeleri yer alır. Bu ifadeler ile ordu içine sızan ajanların yürüttüğü propaganda faaliyetlerinin ne kadar tehlikeli olduğu vurgulanmak istenmiştir (Sasson, 1969, s. 41; Şahin ve Sağır, 2018, s. 4105-4106).

\section{Sonuç}

Kuzeybatı İran coğrafyasının farklı noktalarında İspuni-Menua ortak krallık dönemine ait Kalatgah ve Kelişin yazıtları, Menua Dönemi'ne ait Ain-e Rum, Uşnu ve Taştepe yazıtları, Argişsti I dönemine ait Javankale yazıtı, Sarduri II dönemine ait Sığındıl yazıtı, Rusa I dönemine ait Mahmud Abad, Mergeh Karvan ve Movana yazıtları, Argişsti II dönemine ait Naşteban, Razlık ve Shisheh yazıtları ve Rusa II dönemine ait Maku Kasabası ve Bastam yazıtları tespit edilmiştir. Kelişin, Kalatgah, Uşnu, Mahmud Abad, Taştepe, Movana ve Bastam yazıtları yurt dışında bulunan müzelerde koruma altında iken Ain-e Rum, Sığıldıl, Naşteban, Mergeh Karvan, Razlık, Shisheh ve Javankale yazıtları bulundukları coğrafyada anakaya üzerinde yer almaktadırlar. Bu yazıtlar bulunduğu yüzeyler itibariyle anakaya, sitel, taş levha ve kil tablet üzerine yazılmışlardır. Yazıtların bulunduğu yüzeyler incelendiğinde binlerce yıllık iklim şartlarının etkisiyle çeşitli kısımlarında tahribat meydana geldiği görülür. Bu tahribat yazıtların bazı cümlelerinin tam olarak okunamamasına sebep olmaktadır. 
Kuzeybatı İran Urartu yazıtları türü ve içeriği bakımından incelendiğinde zafer, yapı, adak ve nalet yazıtları şeklinde olduğu görülür. Bunların içerisinde zafer yazıtları çoğunluktadır. Bu tür yazıtlar propaganda değeri yüksek olan içerikleriyle Urartu'nun bölge hakimiyet sınırlarını ortaya çıkarması bakımından önem arz etmektedir. Bu yazıtlarda dil genellikle birinci ağızdan yani kralın dilidir ve din olgusu ön plandadır.

Yazıtlardaki propaganda ifadelerine bakıldığında öncelikle tanıılara karşı saygı sözleri ve gösterişli kral unvanlarının ön plana çıktı̆̆ görülür. Soy belirteci olan baba-oğul ve güç unvanları büyük oranda benzerlik gösterir. Fakat devlet sınırlarındaki genişlemeye paralel olarak kral unvanlarında da farklılaşmalar oluşmuştur. Kuzeybatı İran bölgesi içerisinde ele geçirilen çeşitli ülke ve şehir isimlerinin kraldan krala farklılık gösterecek şekilde kral unvanları ile birlikte anılması her kralın kendine ve egemenlik alanına özgü bir unvan ve dolayısıyla bir propaganda çeșidinin olduğunu ortaya çıkarır. Kralın meşruiyetinin halk bilincinde yer etme çabasını ortaya koyması bakımından bu unvanlar önemlidir ve dinsel gücün ağır bastı̆̆1 siyasi propaganda özelliği taşımaktadır.

Yazıtlarda Urartu krallarının Kuzeybatı İan bölgesine yapılan seferlerde elde etmiş oldukları başarılar ve ele geçirilen bölgede yürütülen faaliyetler yer yer abartılı bir şekilde anlatılmışır. Bu noktada da verilen ifadeler krallar arasında farklılık arz etmektedir. Bunu Sığındıl yazıtında olduğu gibi, bir gün içinde ele geçirilmesi imkansız gibi görülen ülke ve şehir sayısının propaganda yönlü bir dil ile abartılı bir şekilde verilmesinden çıkarabiliriz. Sayısal istatiksellerin verildiği bu ifade tarzı mantıksal bir propaganda yapıldığını ortaya koyar. Kuzeybatı İran Urartu yazıtlarında sıklıkla değinilen konulardan biri imar faaliyetleridir. Başta tapınak ve kale olmak üzere yürütülen bu imar faaliyetleri ele geçirilen bölgenin ihtiyacına göre şekillenmektedir. Menua'nın Uşnu yazıtında olduğu gibi her kral yazıtında inşa ettirdiği yapıyı olağan üstü bir şekilde anlatmaktadır. Ülke kalkınmasını ön planda tutan imar faaliyetlerini konu alan bu ifadeler politik, sosyolojik ve bütünleştirici yönü ağır basan bir propaganda niteliğindedir.

Kuzeybatı İran Urartu yazıtlarında özellikle üzerinde durulan konulardan biri de dini tören, bayram ve kutlamalardır. Urartu krallarının yazıtlarında çokça yer alan bu etkinliklerde tanrıların büyüklügünü ve eşsizliğini ortaya koyan ifadelerle birlikte onlara sunulan adaklardan bahsedilir. Bu etkinlikler anlatilırken kralların kullandığı ifadeler farklılık göstermektedir. Genellikle Urartu'nun en büyük üç tanrısı Haldi, Teişseba ve Sivini onuruna törenler yapılıp kurbanlar kesilmesine rağmen, Mahmud Abad yazıtında olduğu gibi Şebitu ve Artu'arasau adında farklı yerel tanrı isimlerinin geçmesi Urartu bölge hakimiyeti adına hoşgörü siyaseti doğrultusunda yerel değerlere verilen önemi ortaya koyar. Bu ifadeler ile dini gücün himayesi altında kralın rakipsiz tek kişi olduğu vurgusu yapılmıştır. Toplumsal birlik ve bütünlüğü de ön plana aldığ1 için propaganda olarak bütünleştirici yönü de ağır basmaktadır.

Kuzeybatı İran Urartu yazıtlarında propaganda değeri yüksek olan bölümlerden biri de lanet ifadelerinin geçtiği cümlelerdir. Bu yazıtların hemen hemen hepsinin son satırlarında yer alan bu ifadeler kralların kullandığı dile göre farklılıklar göstermektedir. Kelişin yazıtında "soyu sopu yok olsun, yeryüzünden yok olsun" gibi ifadeler yer alırken, Razlık yazıtında "güneş ışı̆ğndan yoksun olsun" gibi farklı ifadeler geçmektedir. Böylece kralın buyruklarına karşı gelenler ve bu buyrukların yazılı olduğu siteli tahrip edenler tanrıları huzurunda lanetlenmişlerdir. Bu ifadeler bir nevi günümüz kara propagandasının bir çeşididir.

Urartu krallarının Kuzeybatı İran hakimiyet sahasında tespit edilmiş olan bu yazıtlarda yer alan propaganda ifadeleri kraldan krala farklılık göstermesine rağmen Urartu'ya has genel bir devlet politikas1 tarzı olduğunu ortaya koymaktadır. Bu tarz Urartu Devleti'nin genişlemesine paralel olarak kralların söylem dilinde farklılıklara neden olmuştur. Toplumsal uyarıcı olarak hükmeden kralı hakim, gücünü ise etkin kılmaya yönelik olan bu söylem dilinin Urartu Devleti’nin genişlemesindeki rolü büyüktür.

Urartu yazıtlarında farklı şekillerde yer bulan propaganda ifadeleri psikolojik olarak insan bilincini etkilemeyi ön plana alır. Ve bu yapılırken yazıtlar bir araç olarak etkin kullanılmıştır. Eski Çağ Ön Asya yazıtlarının birçoğunda bunu görmek mümkündür. Kuzeybatı İran Urartu yazıtlarında geçen propaganda ifadelerine başka bir açıdan bakıldığında bu ifadeler krallığın diplomasi dilini yansıtmakla birlikte devletlerarası bir propaganda savaşının da olduğunu ortaya koyar. Çünkü Eski Çağ Ön Asya krallarının yazıtlarında geçen propaganda ifadeleri ile karşılaştırıldığında karşılıklı bir üstün gelme mücadelesinin olduğu görülür. Eski Çağ Ön Asya’sında adını duyuran Asur, Pers, Hitit, Babil gibi önemli siyasi oluşumlara hükmeden krallar yazıtlarında farklı söylem dili kullanmalarına rağmen aynı amaçlara hizmet eden propaganda metotlarına başvurmuşlardır. Ön Asya dünyasında kralların propaganda araçları ve bu propaganda araçları ile topluma iletmek istedikleri mesajların benzerlerini, insanın binlerce yıllık süreçteki bilgi, beceri ve tecrübelerindeki gelişmeye paralel olarak günümüz dünyasinda da görmek mümkündür. 
Özellikle ileri teknoloji ürünü olan haberleşme araçları kullanılarak yapılan propaganda faaliyetlerinin günümüz dünyası soğuk ve sıcak savaşlarında ne kadar etkin olarak kullanıldığı düşünüldüğünde eski çağlardan günümüze değin uygulanan propaganda faaliyetlerinin nasıl bir değişim ve gelişim içinde olduğu ortaya çıkar. Geçmişte yazı sınırlı sayıda bir kesim tarafindan sınırlı sayıda araçlarla kullanılmaktaydı. Fakat günümüzde bu durum değişmiştir. Birbirinden farklı iletişim araçlarının içinde özellikle dijital ortamın sunduğu kolaylıklar ile iletişim alanında hem yazılı hem görsel hem de işitsel olarak büyük bir ilerleme kaydedilmiştir. Bu durum günümüzde uygulanan propaganda içerikli mesajların, dünyanın neresinde olursa olsun sınır tanımaksızın toplumun her kademesine kolay bir şekilde ulaşmasını sağlamıştır.

\section{Etik Beyan}

"Kuzeybatı Iran'daki Urartu Yą̧tlarndaki Savaş ve Propaganda Ifadeleri” başlıklı çalışmanın yazım sürecinde bilimsel, etik ve alıntı kurallarına uyulmuş; toplanan veriler üzerinde herhangi bir tahrifat yapılmamıs ve bu çalışma herhangi başka bir akademik yayın ortamına değerlendirme için gönderilmemiştir. Bu araştırma doküman incelemesine dayalı olarak yapıldığından etik kurul kararı zorunluluğu bulunmamaktadır.

\section{Kaynaklar}

Akkuş Mutlu, S. (2017). Asur ve Urartu Devleti’nin Manna Ülkesi Üzerindeki Hakimiyet Politikası. Akademik Tarih ve Dïsünce Dergisi, IV (XI), 219-231.

Atalay, İ. (2011). Dünya Coğrafyası. İstanbul.

Basello, G. P. (2013). Persçe: Bir Kral Üç Dil. Aktuiel Arkeoloji (Anadolu'nun Kayıp Dilleri), 36, 132-143.

Belck, W.-Lehmann, C. F. (1892). Ueber neuerlich aufgefundene Keilinschriften in russisch und türkisch Armenien. Zeitschrift für Ethnologie, 24, 122-152.

Benedict, W. C. (1965). Two Urartian Inscriptions from Azerbaijan. Journal of Cuneiform Studies, 19, 35-40.

Brown, B. (1948). Excavation in Azerbaidjan Geoy Tepe, London.

Burney, C. A. ve Lang, D. M. (1972). The People of the Hill. Ancient Ararat and Caucasus, New York.

Burney, C. A. ve Lang, D. M. (1975). Die Bergvolker Vorderasiens, Armenien und der Kaukasus von der Vorzeit bis zum Mongolensturm, Essen.

Ceylan, A. (1991). MÖ II. Bindeki Anadolu'daki Devletlerarası Ilişkiler (antlasmalar) (Yüksek Lisans Tezi). Atatürk Üniversitesi Sosyal Bilimler Enstitüsü, Erzurum.

Ceylan, A. (1994). Eski Anadolu'da Devletlerarası Illiskiler, Antlasmalar (II. ve I. Binde) (Doktora Tezi). Atatürk Üniversitesi Sosyal Bilimler Enstitüsü, Erzurum.

Ceylan, A. (2008). Doğu Anadolu Araştrmalar Erzurum-Erzincan-Kars-Iğder (1998-2008), Erzurum.

Ceylan, A. ve Ceylan, N. (2015). Kavuştuk Yazıtı ve Değerlendirilmesi. Belg̈̈, 1(1), 9-14.

Ceylan, A. ve Ceylan, N. (2016). İran Coğrafyasinda Urartular. Kafdağg, 1, 11-34.

Ceylan, A. ve Günaşdı, Y. (2015). Erzurum ve Çevresindeki Urartu Yazıtlarının Tarihi Açıdan Değerlendirilmesi. Akademik Tarib ve Düsïnce Dergisi, IV(XIII), 313-350.

Ceylan, N. (2015a). Kuzeybatı İran'da Önemli Bir Yerleşme: Hasanlu. Trakya Üniversitesi Edebiyat Fakiultesi Dergisi, $5(9), 189-221$.

Ceylan, N. (2015b). Urartular'n İran'daki Krali Kenti: BASTAM. Ardaban Üniversitesi İnsani Bilimler ve Edebiyat Fakiiltesi Dergisi, 2, 137-158.

Ceylan, N. (2015c). Kuzeybatı İran'da Urartu Yerleşmeleri (Doktora Tezi). Kafkas Üniversitesi Sosyal Bilimler Enstitüsü, Kars.

Ceylan, N. ve Jalalı, L. (2018). Kuzeybatı İran'da Yer Alan Haftavan Yerleşmesine Bir Bakış. Kafkas Üniversitesi Sosyal Bilimler Enstitiusï Dergisi, 22, 673-688.

Çilingiroğlu, A. (1983). Urartu’da Toplu Nüfus Aktarımları. Anadolu Arasttrmalar, IX, 311-323.

Çilingiroğlu, A. (1994) Urartu Taribi. Bornova.

Çilingiroğlu, A. (1997). Urartu Krallŭ̆ Taribi ve Sanatı. İzmir.

Diakonof, I. M. (1988). O Nekotorih Napravleniyaç V Urartskom yazikoznanıyı İ Novih Martskih Tekstah. HA-DV, 5, 133-180.

Diakonof, I. M. (1989). On Some New Trends in Urartu Philology and Some New Urartian Texts. AMI, 22, 77-102.

Diakonof, I. M. ve Kashkai, S. M. (1981). Geographical Names Accordin to Urartian Texts, Wiesbaden.

Dinçol, A. M. ve Dinçol, B. (2003). Urartu Krallığ’’nda Dil ve Yazı. Filiz Özdem (Ed.), Urartu: Savas ve Estetite (ss. 119-127), İstanbul.

Dumlu, A. (2015). Erzurum ve Cevresindeki Urartu Yažtlarnda Gegen Yer İsimlerinin Lokalizasyonu (Yüksek Lisans Tezi). Kafkas Üniversitesi Sosyal Bilimler Enstitüsü, Kars.

Dyson, R. H. (1965). Problems of Protohistoric Iran as seen from Hasanlu. JNES, XXIV, 193-217.

Dyson, R. H. ve Young, T. C. (1960). "Pisdeli Tepe", Antiquity, s. 19-28.

Edmonds C. J. (1966) Some Ancient Monuments on the Iraqi-Persian Boundary. Iraq 28, 159-163.

Edward, M. (1981). The Pottery of Heftavan VIB (Urmia Ware). Iran, XIX, 101-140.

Efşar, S. İ. (1990). Doğu Zerbaycan Mecmuai Ez Ouฉ̨a e Taribi, İctimai ve İktisadi. Tahran. 
Erzen, A. (1992). Doğu Anadolu ve Urartular. Ankara.

Frankel, D. (1979). The Ancient Kingdom of Urartu. London.

Götze, A. (1930). Zur Klischin-Stele. ZA, 5, 99-128.

Grayson, A. K. (1972). Assyrian Royal Inscriptions, I, Weisbaden.

Hacizade, K. (1995). A. Study of Urartian Settlemen in the N. W. Iran (700-900 BC) (Doktora Tezi). Tahran Tarbiat Müderris Üniversitesi.

Hamaçi, B. (1991). Ferhengi Coğrafyayn Az̨erbaycan-ı Şarklı Menatıkı Mübimmi Coğrafyayı Tahran. Tahran.

Hole, F. (1987). The Archaelogy of Western Iran Settlement and Society from Prehistory to the Islamic Conquest. Paleorient, 14-1, 177-179.

Hulin, P. (1958). Urartian Stones in the Van Museum. AS, 8,235-244.

Karauğuz, G. (2002). Boğąköy ve Ugarit Civi Yaz̧l Belgelerine Göre Hitit Devletinin Siyasi Antlaşma Metinleri. Konya.

Kılıç, Y. ve Eser, E. (2016). Urartu yazıtları 1şığında din-siyaset ilişkisi üzerine bir değerlendirme. Belgi, 12, 268 -289.

Kleıss, W. (1972). Bericht uber Erkundungsfahrten in Iran im Jahre 1971. AMI, V, 135-242.

Kleiss, W. (1977). Urartaische Platze in Iran: A. Architektur (Stand der Forschung Herbst 1976). Archäologischer Mitteilungen aus Iran X, 53-83.

Kleiss, W. (1980). Bastam, an Urartian Citadel Complex of the Seventy Century B. C. American Journal of Archaeology, 84(3), 299-304.

Kleiss, W. ve Hauptman, H. (1976). Topographische Karte Von Urartu. Berlin.

König, F. W. (1953-1957). Handbuch Der Chaldischen Inschriften, Archiv Für Orientforschung Heraussgegeben Von Ernst (HChI). Weidner, Beiheft 8, Graz.

Kroll, S. (2011). “İran'daki Urartu Şehirleri/Urartian Cities in Iran”, Köroğlu, K.-Konyar, E. (Eds.)Urartu: Doğuda Değisisim (ss.150-169), , İstanbul.

Kuhrt, A. (2007). The Persian Empire-A Corpus of Sources from the Achaemenid Period. London-New York.

Kuhrt, A. (2013). Eskiçă̆’da Yakindoğu I (M.Ö. 3000-330), Çev. Dilek Şendil. İstanbul.

Küçükbezci, H. G. (2019). "Hitit İnancında Farklı Kurban ve Sunu Türleri”, Selçuk Üniversitesi Sosyal Bilimler Enstitüsü Dergisi, 41, 139-147.

Lehmann-Haupt (1928-35). Corpus Inscriptionum Chaldicarum I-II, Berlin, Leipzig.

Luckenbill, D. D. (1926). Ancient Records Of Assyria And Babylonia I (ARAB). Chicago.

Luckenbill, D. D. (1927). Ancient Records Of Assyria And Babylonia II (AR AB). Chicago.

Mayer, W. (2013). Assyrien und Urartu II, Ugarit-Verlag Münster.

Melikishvili, G. A. (1960a). Urartskie Klinobraznye Nadpisi (UKN). Moskova.

Melikishvili, G. A. (1960b). Eine neue urartäische lnschrift aus den Iranischen Azerbaidschen. Oriental Studies, 29-37.

Melikishvili, G. A. (1960c). Novaya urartskaya nadpis iz Iranskogo Azerbayddjana. Vostocniysbornik, I, 59-74.

Melikishvili, G. A. (1971). Urartskie Klinobraznye Nadpisi, II, Otkritiya i Publikatsiyi 1954-1970gg. VDI (3), 227-255; (4), 265-293.

Muscarella, O. W. (1986). The Location of Ulhu and Uise in Sargon II's Eighth Campaing. Journal of Field Archaeology (JFA), 13(4), 465-475.

Nissen, H. J. (2004). Ana Hatlaryla Mezopotamya. İstanbul.

Özgül, O. (2015). Çoruh ve Kür Vadisinde Kimmer-İskit Yer Adları. Belgü, 2, 159-179.

Özgül, O. ve Ceylan, N. (2017). Eskiçağda Kafkasya Geçitleri (Daryal ve Derbent). Akademik Tarih ve Düşünce Dergisi, IV(XIII), 24-62.

Payne, M. (2006) Urartu Civi Yą̣lı Belgeler Kataloğu. İstanbul.

Perfereç, E. (2001). Kuzeybatı Iran'da Gri Canak-Çömleğin Değişim Süreci (Yüksek Lisans Tezi).Tarbiat Müderris Üniversitesi, Tahran.

Perfereç, E. (2007). İran'ın Kuzeybatısmmn Demirçă̆ İncelemesi, Erdebil'in Şebriyar Bölgesi ve Cevresindeki Kalelerin Çalısılması (Doktora Tezi). Tarbiat Müderris Üniversitesi, Tahran.

Pinarcık, P. (2014). Sargon’un Sekizinci sefer Lokalizasyon Önerileri ve Bu Önerilerin Harita Üzerinde Gösterilmesi. Akademik Sosyal Araştirmalar Dergisi, 7, 38-59.

Piotrovsky, B. B. (1959). Vanskoje Carstvo (Urartu). Moskova.

Poebel, A. (1942). The Assyrian King List From Khorsabad. Journal Of Near Eastern Studies, 1(3), 247-306

Reisnia, R. H. (1989). Azerbaycan der Seyri Taribi Iran: Ez. Ağaz Ta İlam I. Tebriz.

Salvini, A. ve Salvini, M. (2002). The Bilingual Stele of Rusa I Movana (West Azerbaijan, Iran). Studi Micenei Ed EgeoAnatolici, 44(1), 5-66.

Salvini, M. (1977). Eine neue urartaische Inschrift aus Mahmud Abad (West-Azerbaidjan). AMI, 10, 125-136.

Salvini, M. (1981). Utoçneniya v çtenii dvuh urartskih nadpisey v iranskom Azerbaydjan. I. M. Diakonov (ed.), Drevniy Vostok i mirovaya kultura, Moskova. 69- 73.

Salvini, M. (1982). Die Felsinschrift Sarduris II. in Seqendel (Libliuni). AMI, XV, 97-100.

Salvini, M. (1984). "I documenti", Pecorella, P. E., Salvini M. (eds.), Tra lo Zagros e l'Urmia. Ricerche storiche ed Archeologiche nell'Azerbaigian Iraniano, 53-96.

Salvini, M. (1986). Assyrian and Urartian Written Sources for Urartian History. Sumer, XLII, 155-159.

Salvini, M. (2005). Der Turmtempel (susi) von Bastam. Archaologischer Mitteilungen aus Iran, XXXVII, 371-375.

Salvini, M. (2006). Urartu Taribi ve Kültürü, (Çev. Belgin Aksoy), İstanbul.

Salvini, M. (2008a). Corpus Dei Testi Urartei (CTU), I, Roma. 
Salvini, M. (2008b). Corpus Dei Testi Urartei (CTU), III, Roma.

Salvini, M. ve Salvini, A. (1999). The Urartian rock inscription of Razliq and Nasteban (East Azerbaijan, Iran). SMEA, XLI/1, 17-32.

Sandalgian, J. (1900). Les inscriptions cuneiformes Urartiques: transcrites avec une triple traduction interliruiaire en Armenien c1 assique, en Latin et en Française, suivies d'un glossaire et d'une grammaire, Venedik.

Sasson, J. M. (1969). The Military Establishments at Mari, Roma.

Sayce, A. H. (1882). The cuneiform inscriptions of Van. JRAS 14, no:1-57, 377-732.

Sayce, A. H. (1893). The cuneiform inscriptions of Van, part 4. JRAS 25, 1-39 (no. 69-79).

Sayce, A. H. (1894). The cuneiform inscriptions of Van, part 5. JRAS 26, 691-732 (no. 80-85).

Sayce, A. H. (1901). Fresh contributions to the decipherment of the vannic inscriptions. JRAS, 645-660 (no. 86).

Sayce, A. H. (1906). The cuneiform inscriptions of Van, part 7. JRAS, 611-653, (no. 87-90).

Şahin, H. A. ve Sağır, T. (2018). Eski Babil çağı krallarının istihbarat faaliyetleri. Social Sciences Studies Journal, 4(22), 4104-4110.

Şimşek, O. (2020). Tuzluca İlçesinin İdari sınır ve Yapısında Meydana Gelen Değişiklikler. Kafdă̆ı, 5(1), 18-29.

Talai, H. (1983). Late Bronze Age and Iron Age Architecture in Sagzabad-Qazuin Plain-The Central Plateau of Iran. Ironica Antiqua, XVIII, 51-57.

Tarhan, M. T. (1972). Eskiçă̆da Kimmerler problemi (Doktora Tezi). İstanbul Üniversitesi Edebiyat Fakültesi Tarih Bölümü.

Thureau-Dangin, F. (1912). Hutteme Campagne de Sargon. Paris.

Tosun, M. ve Yalvaç, K. (1989). Sümer, Babil, Asur Kanunlar ve Ammi-Şaduqa Fermanı. Ankara.

Tseretheli, M. (1933). Etudes ourarteennes, 1: La stele de Kelichine. RA, 30, 1-49.

Tseretheli, M. (1935). Etudes ourarteennes, 1: La stele de Kelichine. RA, 32, 57-85.

Tseretheli, M. (1953). Etudes ourarteennes, 4: La stele de Kelichine. RA, 47, 131-140.

Tuncel, M. (1991). Aras. Diyanet Vakfi İslam Ansiklopedisi, III, 332-335.

Van Loon, M. N. (1975). The inscription of 1shpuini and menua at qalatgah. Journal of Near Eastern Studies (JNES), 34(3), 201-207.

Yiğit, T. (2003). Hitit krallığg’'nda veliahdın belirlenmesi üzerine. Tarih Araştırmalar Dergisi, 34, 141-147.

Yiğit, T., Özcan, A. ve Kuymet, K. (2016). Hitit imparatorluk dönemi kaya anttlar. Ankara.

Zimansky, P. (1985). Ecolgy and empire: The structure of the urartian State. Chicago.

\section{EXTENDED ABSTRACT}

Azerbaijan Plateau in the northwest of Iran constitutes the majority of the Iranian Plateau. This plateau is in the form of a triangle between Mesopotamia, the Caucasus Region and the Caspian Sea. The high snowy mountain range of the northwestern part forms the border wall of the Northwest Iran Region. Kaflankuh in the east, Sehend Mountain in the south, Savalan and Bozkuş Mountains in the northeast and Urmiye Lake in the west surround this area. While there are rivers such as Aras River, Red Long River, Bitter Stream in the East Azerbaijan part of the Northwest Iran Region, there are main rivers such as Küçük Zap, Sarısu River, Ovacık River, Zengimar River, Dir Alisu, Zerin Dere and Zorlay Stream in the West Azerbaijan section.

The fertility of the soil in North West Iran, the suitability of the climatic conditions and the vegetation, the existence of sufficient conditions for hunting and gathering caused the region to be settled in various periods of the history. Findings obtained in researches conducted in various centers in the region prove this situation. One of the places in this geography is the Urmia Region. Urmia Lake, which is mentioned as the Lower Sea of Nairi in the Assyrian geographic texts, is one of the important water resources of the region. Urmiye Lake and its surroundings, which have been settled since the early periods of history, is a strategically important region with the ease of transportation they provide to neighboring countries as well as their military and cultural value. One of the important countries located in the North West Iran region and at the focal point of Urartu and Assyrian military expeditions is Manna Country. Scientists have different opinions about the localization of this country, which is in a strategic position for both Assyria and Urartu in terms of natural resources and location. However, it is generally placed on the southern shores of Lake Urmia. Other important regions, countries and cities in northwestern Iran and mentioned in the Urartu inscriptions are; Hubuşkia Region, Barşua Country, Bushtu Country, Gilzanu (Hasanlu) Country, Ulhu Country, Bastam and Musaşir cities.

Since the establishment of the Urartu State in the IX century BC, almost all Urartu kings have shown interest in the northwestern Iranian geography. This region, which is the scene of intensive UrartuAssyrian struggles, has constantly changed hands between these two great powers. The Urartian kings organized many expeditions to this region and carried out various construction activities to strengthen their dominance in the region. We learn about the activities of Urartu on the northwestern Iranian 
geography from the inscriptions left by the Urartu kings to different parts of this geography. Kalatgah belonging to the joint kingdom of Ishpuini and Menua, Kelishin inscriptions, Ain-e Rum, Uşnu, Taştepe inscriptions belonging to the Menua period, Javankale inscription belonging to Argishti I period, Sığdıl inscription belonging to the period of Sarduri II, Mahmud Abad, Mergeh Karvan, Movana inscriptions, Nasteban, Razlik, Shisheh inscriptions belonging to the period of Argishti II and the Ruins of Maku Town and Bastam inscriptions belonging to the period of Rusa II are the main inscriptions revealing the Northwest Iran domination of Urartu.

Urartian inscriptions are divided into types such as victory inscriptions, votive inscriptions, building inscriptions, canal inscriptions, warehouse inscriptions and curse inscriptions. Looking at the types of inscriptions, some are annuals and describe the victories of kings. These inscriptions are mostly found in Ispuni-Menua, Menua, Argişti I and Sarduri II periods. Another type of inscription is building inscriptions. Although this type of inscription is encountered in all periods of the Urartu kingdom, it is mostly seen in the Menua period.

War and propaganda texts included in the Urartian cuneiform documents are of particular importance. The propaganda expressions in these texts convey to us from the language of the Urartu kings, especially the political and religious, cultural, economic and similar features that prevailed in Asia Minor. This language is a propaganda language and reveals how the Urartu kings combined political and religious power to direct the society. When the propaganda expressions in the Urartian inscriptions are examined, besides the king titles, the shepherd-king metaphors that reveal that the king is the loyal servant of the god and the leader of his people, the sacrifices are made in honor of the gods; killing or forgiveness of the king, who was to be pardoned and tribute, when the new king was appointed to the captured country with the permission of the Urartu king, an exaggerated explanation of the capture of many castles and cities in one day during the expedition, and the denial of the king's orders at the end of the inscriptions and the destruction of the inscriptions on which these orders were written. expressions such as the condemnation of the punishment were intended to be conveyed to human masses with a high rhetorical power. When the propaganda expressions in the Urartian inscriptions are evaluated in the light of the Ancient Front Asian inscriptions, it is seen that they have many similar aspects. As in the Urartian inscriptions, in other Front Asian inscriptions, the language is usually the first person, that is the language of the king, and the phenomenon of religion is in the foreground. The titles of the glorious king, the victories won, the activities carried out in the area seized are described in an exaggerated way. As in the Urartian inscriptions, those who opposed the king's orders were harshly warned in the Front Asian inscriptions. Again, events such as ceremonies, festivals, and celebrations held to ensure unity and integrity among the people are also mentioned in the Front Asian inscriptions. 